Estonian Journal of Archaeology, 2004, 8, 2, 128-162

\title{
Marika Mägi \\ “... SHIPS ARE THEIR MAIN STRENGTH." HARBOUR SITES, ARABLE LANDS AND CHIEFTAINS ON SAAREMAA
}

The article is an overview of archaeological research done in recent years on the prehistoric and medieval maritime landscapes of Saaremaa, the biggest Estonian island. Coastal settlements in this area were considered as inseparable from maritime activities, which are reliably indicated by ancient harbour sites. Criteria for distinguishing earlier harbour sites, as well as their typical features and the connection with their agrarian hinterland are analysed both on Saaremaa and in other regions around the Baltic. Attention is also paid to social development, and how it was reflected in the distribution and character of harbours. The first distinguishable harbour sites on Saaremaa are briefly described, analysing their origin and development in a broader international context.

Artikkel võtab kokku viimaste aastate uurimistöö Saaremaa muinas- ja keskaegse merendusliku maastiku vallas. Uurimise lähtekohaks on tees rannaäärsete asustusüksuste ning merendusliku tegevuse lahutamatust seosest, mille üheks sümboliks on kunagised sadamakohad. Artiklis on vaadeldud nende leidmise kriteeriume, iseloomulikke jooni ning seost agraarse tagamaaga nii Saaremaal kui ka Läänemerd ümbritsevates maades laiemalt. Tähelepanu on pööratud sadamakohtade levikus kajastuvale ühiskondlikule arengule. Lühidalt on kirjeldatud esimesi seni identifitseeritud muistseid sadamakohti Saaremaal, nende tekkimist ja arengut on analüüsitud laiemas rahvusvahelises kontekstis.

Marika Mägi, Ajaloo Instituut (Institute of History), Rüütli 6, 10130 Tallinn, Estonia; Marika.Magi@mail.ee

It would be difficult to find another prehistoric Estonian district bound so strongly to the sea as Saaremaa. The role of maritime activities in its subsistence system was primarily defined by the insular location of the district, more precisely its spread across several islands. ${ }^{1}$ Various imported items among the otherwise local archaeological material give evidence of overseas communication, and even

1 The name Saaremaa (Ösel) is used here, as in the Middle Ages and probably earlier, to mean "The District of Islands". The name thus embraces not only the present Saaremaa but also the island of Muhu, as well as Sõrve, Kõrkvere and others that were islands or islets during the prehistoric and medieval periods (Mägi 2002c). 
the settlement pattern is clearly oriented towards the coastline. Early medieval written sources emphasize without exception the power of the Osilian navy and the secure situation of the Osilians, especially in summer time when it was impossible to reach the island without using sea vessels.

"The Osilians are wicked Pagans, they are the neighbours of the Curonians.

Their land is surrounded by sea, They are never afraid of large armies;

In summer time, we know that

They plunder surrounding lands,

Which can be reached by sea...

... Ships are their main strength."

(Older Rhyme Chronicle, 357-367)

Nevertheless, the maritime activity of the Osilians was certainly not confined to plundering. Fishery and seal hunting, as well as barter and control over international trade might have actually played much more important roles in the local economy.

This article is an overview of what has been done in the research of Osilian maritime landscapes in the last decade. In this, the main attention was paid to the last prehistoric centuries and to the (local) early Middle Ages, that is, to the period 900-1400. It covers both the Viking Age and the 12th century, the era of prosperity for Saaremaa, as well as the obscure and controversial 13th and 14th centuries when Saaremaa still kept a great part of its one-time supremacy.

The study of Osilian maritime landscapes started as early as in the middle of the 1990s, when a number of prehistoric harbour sites were detected as a result of theoretical constructions and several surface survey trips. The financing of the "Coastal Settlements on Prehistoric and Medieval Saaremaa" (Estonian Science Foundation Grant No 5432), started in 2003, made it possible to intensify the research. This article is among the first publications scheduled in the framework of the project.

\section{Research material}

\subsection{Agrarian and maritime landscapes}

In areas closely connected to the sea, the terrestrial/agricultural and maritime (cultural) landscapes should be considered in their mutual relation and interaction. On the island(s) of Saaremaa, due to its geographical position, one cannot overestimate the significance of the sea in the archaeological interpretation of a cultural landscape. The soil of these islands is usually thin and infertile, and cattle breeding

2 Free translation by the author of the article. 
has been believed to be relevant for the local subsistence industries. Maritime activities - fishing, seal hunting, barter - have always been of great importance on the islands.

There is however no doubt that settlement units on prehistoric and medieval Saaremaa were first of all agrarian. A settlement unit consisted of dwellings and other buildings, arable lands, meadows, pastures, forests and other components used by its inhabitants. The settlement unit was normally an independent economic unit and thereby distinguishable from other similar ones within the same area. The traces of former settlement units preserved up to the present comprise primarily archaeological sites such as e.g. hill-forts, dwelling sites, cemeteries, cult places, and fossil fields. The landscape maintaining these traces, i.e. physical terrain influenced by human activity, can be designated as the cultural landscape.

Whether the primary settlement units on Saaremaa were predominantly villages or single farmsteads is not known. No archaeological excavations have been carried out at these sites, and the former settlement units were, therefore, traced back with the help of other types of archaeological sites, mainly stone graves, hill-forts and ancient field patterns.

In the areas immediately bordering the coast, an important additional aspect must be taken into consideration and treated in close connection with the characteristics of the settlement structure described above. This aspect comprises all kinds of maritime activities and their relationship with their immediate surroundings. In terms of archaeology, the maritime activities are observable through, for instance, ancient harbour sites, shipwrecks and remains of bridges. As a result of mutual influences and a dense interaction of human behaviour, physical coastal landscape and topography of the near-shore sea, a maritime cultural landscape is formed.

\subsection{Harbour sites}

It is essential to define where the border lies between (pre)historic harbour sites and other places which were suitable for landing boats and other watercraft. There is no doubt that the functions of the sites were different, although often overlapping; the sites can also be differentiated according to how intensively they were used. An important aspect is the socio-political location in cultural landscapes: the hinterland, and especially the connection between the harbour/landing site and the closest political, economic, cult or other centres.

The terms used so far are, however, understood differently by different researchers. Danish archaeologist Jens Ulriksen has called all sites of this type landing-places, which are defined as follows:

"A 'landing-place' is a functionally neutral term for a site that has been directly related to seafaring, in other words, a site oriented to maritime activities" (Ulriksen 1998, 13, 259).

Gotland researcher Dan Carlsson mentions harbour sites and trading centres; still, not all harbour sites need be trading centres (Carlsson 1991). Some archaeo- 
logists prefer to talk only of trade centres, where, however, traces of workshops can also be found (e.g. Callmer 1991). On the other hand, the term harbour (and harbour site, especially when the site is abandoned) is ingrained in different languages, meaning sites starting from village or farm harbours with very limited importance up to large central city harbours. Seldom used and unimportant places for landing boats are, nevertheless, seldom observable in archaeological terms. Taking into consideration these arguments, and also reckoning with the fact that the term has already become familiar in Estonian archaeological literature, I have preferred to use harbour site instead of the much more general landing-place/site. In doing this, it is essential to distinguish harbour sites with different functions and importance.

A harbour site can thus be defined as a place oriented to maritime activities and accessible to water vessels, and a place whose use is regulated by agreements and/or tradition and which comprises a hinterland. Accordingly, landing-places with accidental character cannot be interpreted as harbour sites in this text; in practice, it is almost impossible to distinguish them archaeologically.

The hinterland of a harbour site is the area with which one or another function of the harbour site is directly connected. The size of the hinterland varies according to the function and importance of the harbour site. The hinterland of a harbour site characterised by fishing, barter and communication at the local level is formed by the agrarian settlement unit(s) using the harbour. The hinterland of a harbour site which functions as a trade centre is normally a bigger prehistoric district, e.g. a district corresponding to a later parish. ${ }^{3}$ Harbours in urban centres were usually connected to international trade, and their hinterlands can embrace whole regions. On Saaremaa, however, no urban centres emerged before the 16th century.

\subsection{Research history}

In many countries, the cultural (mainly agricultural) landscape has been the subject of archaeological investigation for a long time. In the North, however, special attention to the ancient settlement pattern in the coastal areas has been paid only in Scandinavia during the last 20-25 years. First of all, the research of Carlsson on the island of Gotland should be mentioned; this has provided an entirely new point of view on the ancient cultural landscapes and, thereby, on ancient societies. As a result of many archaeological inventories and excavations, Carlsson has discovered approximately 50 prehistoric harbour sites located along the coast of Gotland. Studying the establishment and development of these harbour sites, he pays much attention to their close relationship to other contemporary elements of the cultural landscape within the same area, in order to demonstrate the mutually complementary nature of the agricultural/terrestrial and maritime cultural landscapes (Carlsson 1992; 1998; 1999b).

3 In medieval (and later) Estonia, parishes were bigger than in other northern countries and can also be considered as administrative units. 
Since the 1980s, the concept of maritime cultural landscape has also received much attention in mainland Swedish maritime and underwater archaeology. In the research there, the investigation of sailing routes, harbour sites, shipwrecks and other archaeological sites is combined with cultural history in its widest sense (for instance, toponymy is of great importance in the research); physical characteristics of the landscape such as topographical peculiarities of the coastal regions are also considered (i.e. Westerdahl 1980; 1989).

In Denmark, maritime and agrarian culture landscapes have been the subjects of several research projects. This country, characterised by a very long and heavily indented coastline and a flat coastal area, can often be geographically compared with Estonia. Still, some vital differences between the landscapes of these two countries can also be pointed out, first of all the number of naturally well-protected inlets stretching far into inland Denmark. In prehistoric and early medieval Denmark, the extent of social stratification was also greater. The 8th century, when harbour sites there became clearly evident in archaeological material, was followed, within a couple of centuries, by the formation of a state and conversion to Christianity. Starting from the medieval period, the development of Estonian and Danish harbour places thus continued in somewhat different social conditions. Still, as will be demonstrated below, parallels between Estonian and Danish harbour sites can in some cases be appropriate even in the 11th-12th centuries.

Mainly in the 1990s, a wide-scale research project on the island on Fyn was carried out under the supervision of Ole Crumlin-Pedersen and with the cooperation of several researchers from different fields. The project concentrated on maritime landscapes of the island during the period $500 \mathrm{BC}-1500 \mathrm{AD}$, and resulted in the demonstration not only of interlacing connections between the coastline, maritime activities and arable lands, but also sea routes and neighbouring areas on the other side of the surrounding straits. One of the observations of the research team was that in most periods a coastal zone up to $5 \mathrm{~km}$ in depth could be interpreted as a maritime landscape. Much attention was also paid to historical and topographical material, and to a certain extent also to social conditions (Atlas over Fyns kyst, 1996).

During the same decade, Danish archaeologist Ulriksen supervised several archaeological excavations at landing-places around Roskilde fjord on the island of Zealand. The project was completed with a monograph published in 1998 (Ulriksen 1998). In this, several types of prehistoric and medieval landing-places were distinguished, mainly according to their function and place in the settlement pattern. Ulriksen associated the different types and the development of the landingplaces primarily with political changes that took place in Danish society, which were particularly well indicated by the foundation of early urban trade centres. He also pointed out some criteria for defining ancient harbour sites, which differed from those on Gotland, the most vital of which was the lack of connection between prehistoric graves and the landing-places. At the same time, the attention paid in his book to the connection between the landing-places and arable lands 
was barely sufficient: only the immediate coastal zone was observed in most cases while deeper inland areas were included in the research only occasionally.

The connection between social relations and harbour sites, as well as the direct link between subsistence industries and the possibility of taking part in long distance exchange, has been treated in the research of Ulf Näsman. He has even found it essential to include in the study a number of agrarian settlements further inland, defining the coastal zone as "an approximately $30 \mathrm{~km}$ broad area, that is, an area within which it should be possible to reach the coast in one day" (Näsman 1991).

In Estonia, modern settlement archaeology has been developed primarily by Valter Lang, who has published several books and articles on farming settlement and cultural landscape in North Estonia (e.g. Lang 1996; 2000). Coastal settlements in the same part of the country, including the habitation of riversides, have been observed in articles by Gurly Vedru (Vedru 2001; see also the article in this issue). The concept of maritime cultural landscape, treated in close connection with the Maasi shipwreck found near the coast of Saaremaa, is introduced in an article by Kristin Ilves (Ilves 2002).

Iron Age and medieval settlement archaeology on Saaremaa has been treated in research in recent years by the author of this article (Mägi 1998b; 1999b; 2000; 2001c). Surface survey trips carried out mainly in the second half of the 1990s and early 2000s have resulted in the recording of several prehistoric harbour sites (Fig. 1). These investigations, when compiled with the settlement pattern on pre-

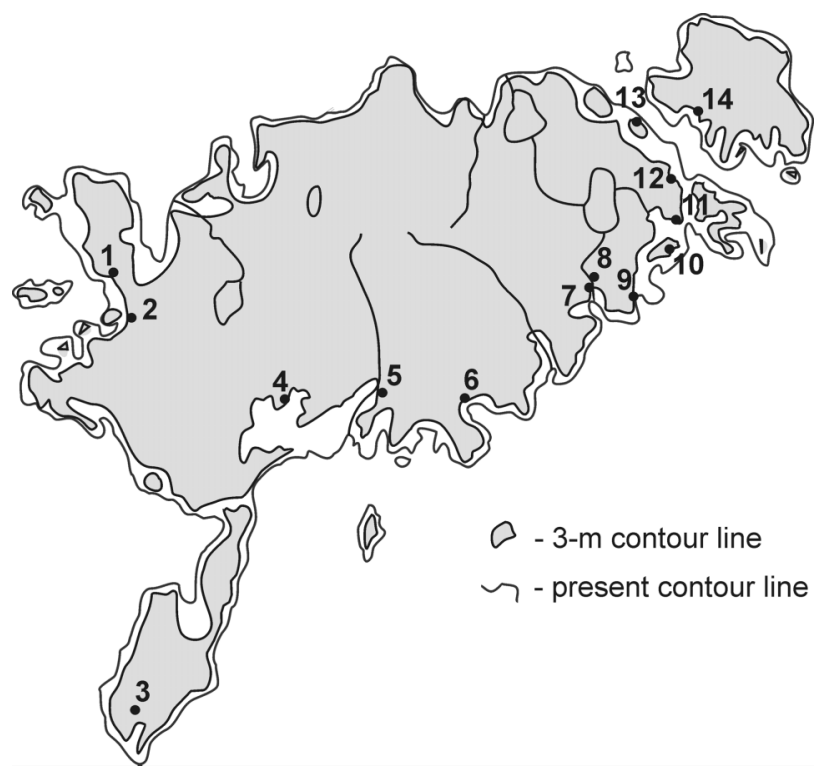

Fig. 1. Saaremaa harbour sites mentioned in the text. 1 Kurevere, 2 Kihelkonna, 3 Lülle, 4 Kogula, 5 Upa, 6 Püha, 7 Kuru Saat/Paemõis, 8 Viltina, 9 Tornimäe, 10 Muhu Linnuse.

Joon 1. Tekstis mainitud sadamakohad Saaremaal. 
historic Saaremaa in general, have indicated that the methods for distinguishing ancient harbour sites, invented by Scandinavian colleagues, can with minor additions also be used on Estonian islands, as well as probably in the rest of the country. Agrarian settlement units on Saaremaa, when possible, have always been directly connected to the sea, harbour site(s) and maritime activities. The same is true for the political and administrative centres on the island.

\section{Harbour sites as archaeological evidence}

\subsection{Search criteria and methods}

As pointed out before, experience and methods worked out by archaeologists in the countries neighbouring Estonia have been largely used in the investigation trips on Saaremaa. This approach presupposes extensive study of the literature and maps before going into the field, as well as the use of phosphate analysis and metal detector on the spot. Since the experimental work in identifying prehistoric harbour sites has however been somewhat different in different countries, methods and indicators best suited for Saaremaa have been selected in the course of the last few years' investigations.

Carlsson has stated three main criteria for distinguishing prehistoric harbour sites on Gotland. These are 1) prehistoric graves or grave-fields close to the coast; 2) a shore protected from strong winds and 3) a situation in the cultural landscape (as seen on the land-survey maps from the 18th and 19th centuries) which diverges from the normal (roads meeting at a certain point on the coast or agricultural land near the coast but no farm within a reasonable distance) (Carlsson 1991). All the abovementioned criteria can be adjusted for Saaremaa, and will be considered more closely below. In addition, the location of early medieval manors has been treated as an indicator of Osilian harbours, and the same is true for medieval churches. In a word, all components of the cultural landscape behind the harbour, the hinterland, can be taken into consideration. Some attention is also paid to toponyms possibly indicating some connection with maritime activities, and local folklore, but these must be considered as supplementary indications in locating prehistoric harbour sites.

After possible prehistoric and medieval harbour sites were selected, comparing the data of historical maps with topographic features taken from modern physical/ geographical maps, these were then checked in the course of archaeological surface survey trips. During the fieldwork, a metal detector and phosphate analysis were used. The first proved to be indispensable in cases when the culture layer was not too thick. The actual detecting depth is dependent on the make of the instrument, the soil, the size and material of the artefact; we used a Minelab Explorer detector that was able to identify metal items to a maximum depth of $30 \mathrm{~cm}$. The use of a metal detector can, however, be less productive at harbour sites whose role during their time of use was more central and where the prehistoric culture layer 
lies deeper, especially when villages or households have been located at the same spot in the following centuries. Since such places cannot be identified with the help of a metal detector alone, trial pits were also dug in order to define the character of the site.

The most essential method in distinguishing prehistoric harbour sites on Saaremaa has proved to be phosphate analysis (for the use of this method in similar research on Gotland see, for example, Österholm 1991; Carlsson 1998). Unfortunately, the use of phosphate analysis on Saaremaa must also be considered to a certain extent problematic, due to the overuse of chemical fertilizers that characterised Soviet-era agriculture. Predominantly because of this, the absolute indexes of phosphate values in samples taken from various districts cannot be compared. The use of the spot-test method on Saaremaa is complicated mainly for the same reason: preliminary trials in spot-tests resulted in values that were completely different from the results that were obtained from a laboratory. All soil samples that were taken in course of the investigation of possible harbour sites were, therefore, analysed in the laboratory, which made the research somewhat slower and more expensive. All soil samples were taken from the deepest level of the culture layer, directly on top of the natural ground. The intensity of the cultural layer was calculated when comparing the phosphate values of the interesting area with that in the surroundings where no cultural layer was detected. In the harbour sites detected so far, the phosphate values exceeded that in the surroundings by an average of 3-4 times.

Some of the probable harbour places where the phosphate values compared to the surroundings were high and/or where prehistoric artefacts were found, were selected for small-scale trial excavations. These, in any case, will be the next step in the Research Project.

\subsection{Representativeness}

In defining harbour sites as an inseparable part of the Osilian settlement pattern, we need to consider whether our sample is representative: how many harbour sites once used have been found or will possibly be found in the future; the finding of how many could be difficult; how large a number of the sites might have been demolished. We have to admit that, with the methods we have in use at present, it is almost impossible to locate seldom and not very intensively used prehistoric harbour sites, much less landing-places. It was agreed, therefore, to investigate harbour sites of somewhat greater significance, whose connection with the hinterlands, marked by archaeological evidence, is observable. On Saaremaa, it should be possible to find primarily district-level harbour sites, or at least to locate these theoretically on a map.

The identification of harbour sites is often complicated by the fact that medieval (coastal) villages were often founded on top of abandoned harbours. Several villages of this sort exist up to the present day. In these cases, a possible prehistoric 
layer has been covered by a later cultural layer and certainly partly demolished by the buildings of the following centuries. Since the Saaremaa landscape has in places been changed beyond recognition by Soviet-era building and development work, it is not uncommon to find the selected place for a harbour site completely destroyed due to agricultural or military structures, or by gravel pits or other activities. An area adjacent to a present-day wetland at Upa, northeast of Kuressaare, can be given as an example (Fig. 2). According to all preliminary characteristics, the place had been suitable for a harbour site a thousand years ago; however, the first visit to the site made it clear that the whole area had been completely altered through drainage and gravel pits (Mägi 2003). If the theoretical reconstructions were correct and a harbour, perhaps even the main harbour of the surrounding district, was situated at this spot in prehistory, it can never be proved.

Analysing the representativeness of landing sites around Roskilde fjord, Ulriksen has assumed that places where the cultural layer contains few metal objects must remain unidentified. The suggestion is based on the fact that more than half of the harbours/landing-places in this area have been recognized by metal detectors (Ulriksen 1998). Nevertheless, a too deeply located layer with (few) metal items can lead to a similarly negative result. Another variant where a metal detector cannot be used is where scrap metal is present in the soil. This is a frequent situation

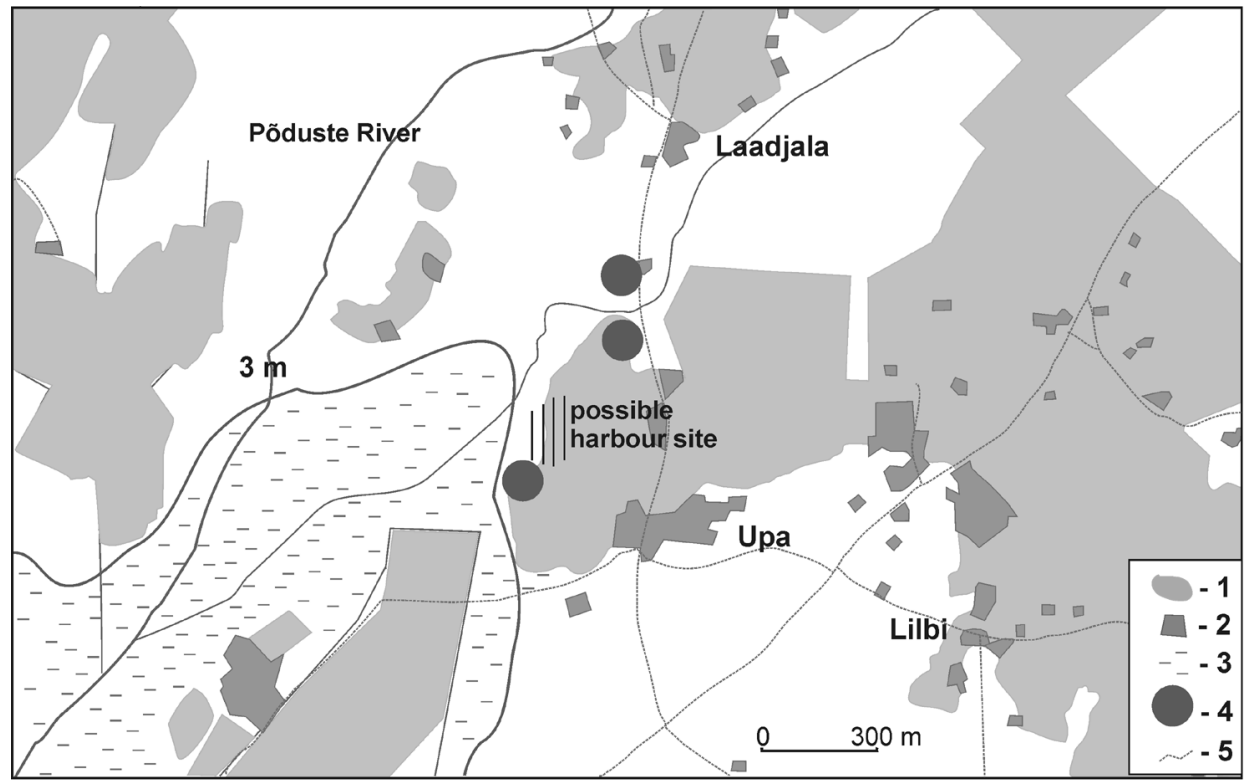

Fig. 2. Possible harbour site at Upa. Drawn using a present day map. 1 arable land (after land development), 2 dwelling site, 3 wetland, 4 demolished stone grave, 5 road.

Joon 2. Võimalik sadamakoht Upas. Joonistatud nüüdisaegse kaardi järgi. 1 põllumaa (pärast maaparandust), 2 asula, 3 liigniiske ala, 4 hävitatud kivikalme, 5 tee. 
on areas of Soviet-era military use, and sometimes also in places associated with kolkhoz agriculture. Some probable historical harbour sites are simply covered by household refuse, thrown there during the last decades.

Probably the most complicated to find are river harbours, whose onetime existence and importance are, at the same time, above suspicion. On the Slavonic coast of the Baltic Sea, a pattern according to which the settlement centre of the harbour was located on banks of a river, some distance away from the sea, has been considered as typical in the Viking Age (e.g. Rẹbkowski 1999). The existence of river harbours on Saaremaa can be suggested predominantly on the southern coast where the sea is often very shallow and the coast flat. In such circumstances, river estuaries with somewhat deeper waters can be the most suitable or even the only places for ships to land. Rivers change their beds over the course of time, especially in flat terrain, and the changes of water level in them are difficult to follow several centuries later. The recognition of river harbour sites, therefore, is not an easy task. In addition, the archaeological finds in such harbour places are probably similar to those found in agrarian settlement sites on river banks, which makes it difficult to differentiate between these two types.

The preconditions for locating prehistoric and medieval harbour sites on Saaremaa are accordingly quite limited. In some cases it is however possible, and the first sites are already recorded. Even these few surviving harbour sites are of vital help in the reconstruction of historical settlement patterns. Some of them have been chosen as selected examples in further research.

\subsection{Location}

Natural landing-places can usually be located on a topographic map. They are as a rule naturally well-protected areas, if possible situated on a heavily indented coastline, generally in places with deeper water near the shore. Frequently, the harbour sites can be found beside small sea bays or what used to be a sea bay in earlier times. To avoid strong winds, places protected by a cape or island in front of the bay were preferred. Suitably steep coasts and rapidly deepening water can be considered as essential preconditions. Shores where the water is shallow up to several hundred metres from the coast were difficult to use for landing even small boats, much less larger craft. It was also complicated when the coast was too steep or very stony. A sea bottom consisting of sand or thinner gravel was an advantage. Frequently, a spring or a river can be found near a harbour site.

At Roskilde fjord, Ulriksen has pointed out that for 6th-12th-century landingplaces, a coastal ridge with hills or rocks on both sides was often chosen. Traces of human activity were also found on these hills (Ulriksen 1998, 113-142). Although this observation cannot be transferred directly to Saaremaa - mainly because of frequent lack of suitable hills and rocks - it is however worth considering in some cases. 
Although the coastline of Saaremaa, as well as of Gotland and Denmark, is often heavily indented, enabling the selection of quite a number of naturally suitable landing-places, harbours were founded only at some of them. Here we face the importance of a hinterland. As far as prehistoric harbour sites on Saaremaa are concerned, direct connection with agrarian hinterlands seems to be a determinant - i.e., they were founded in the vicinity of arable lands (for a similar connection in Sweden see Näsman 1991). All surface survey trips carried out on the island so far have only supported this presumption: no prehistoric harbour sites have been recorded in sandy, stony or otherwise infertile areas. It is essential to note here, anyway, that not only the direct coastal zone but the whole hinterland was taken into account, which means that arable lands can also be situated at a distance of 1-2 kilometres from the coast. A major premise for choosing a place for a harbour is a communication route leading deeper inland: a road or a river. In most cases, harbours seem to have been established as far inland as the draft of sea craft allowed, presumably to minimise the cost of land transportation, to create better access for the people of the surrounding area, and perhaps to secure them against seaward attack.

In addition, the land mass upheaval as a relevant transformation process on the flat coastal areas of Saaremaa should be taken into consideration. The speed of this process has been calculated to be $2.5-3 \mathrm{~m}$ per thousand years, but it varied markedly in different centuries, depending on the height of sea level in warmer or cooler climate periods, the slowing of the upheaval over the course of time, and other factors. Still, the "rule" in the determination of prehistoric and medieval Osilian harbour sites seems to be that it is practical to assume a quicker rather than a slower land mass elevation than the average; that is, the real Viking Age coastline can, in several cases, be found even higher than the 3-m contour line. The same has been recorded on the island of Gotland, which resembles Saaremaa both geographically and in the speed of land mass elevation (Carlsson 1999b, 47-51). Faster accretion of landmass in coastal transformation processes can be for instance calculated in narrow straits, when winds blow predominantly from one direction - that is, in places that very often were natural for harbour sites. The opposite process, when the waves hollow out the coast, mainly characterises shores open to winds - accordingly places that were hardly ever chosen for harbours in prehistory.

It is particularly difficult to reconstruct a coastal landscape when a former sea bay has turned into a bog. Present contour lines of such areas can be even higher than the surroundings and can therefore not be relied on. Unfortunately, Saaremaa has historically been rich in wetlands, though the majority of them have by now been drained and cultivated.

The land mass upheaval, the drainage works, which started as early as the 18 th century, and the straightening of rivers, have thoroughly changed rivers on Saaremaa. Several rivers marked by bold lines on 17th-century maps have turned into small ditches or have completely disappeared by the present day. 
The identification of river harbours and their role in earlier settlement patterns is even more complicated by the fact that, in the flat terrain of Saaremaa, normally very meandering rivers have frequently changed their beds.

\subsection{Archaeological features of harbour sites}

Harbour sites investigated on the banks of Roskilde fjord and on the island of Gotland usually covered an area of 1-5 ha, while traces of human activity were characteristically found mainly along the coast and, to a lesser extent, inland. In most cases, remains of pit-houses and other simple buildings were uncovered. The number of artefacts found at these sites was seldom large, and somewhat surprisingly most of the sites were characterised by lack or shortage of finds directly associated with trade - e.g. scales and weights, coins or imported items. The artefact material - bronze artefacts, ceramics, animal bones - closely resembled that of settlement sites, and the somewhat more frequent occurrence of material related to workshops can be picked out as the only specific feature for harbour sites (Carlsson 1991; Ulriksen 1998, 113-142). In addition, some harbour places were characterised by a higher than normal number of boat rivets, providing evidence of repair work on boats (e.g. Thomsen 1991). Most of the harbour sites were not clearly separated from the surrounding area, and only the bigger Viking Age trade centres around the Baltic were normally surrounded by a semi-circular wall (e.g. Birka, Paviken; see Lundström 1985; Holmquist Olausson 2002).

Björn Ambrosiani has described a harbour site at Hornö, near Birka in central Sweden, as a sandy beach, upon which a pair of stone cairns was detected. Some stone structures were also recorded along the shoreline. Directly inland from these structures there remained an area of high phosphate values and a possible building terrace. The harbour structures had been defended by a hill-fort on a neighbouring hill (Ambrosiani 1991). On a 3rd-7th-century harbour site at Lundeborg on the island of Fyn, the cultural layer was generally $50 \mathrm{~cm}$, in some places up to $80 \mathrm{~cm}$ thick; it stretched out approximately $800 \mathrm{~m}$ along what used to be a small bay. The width of the cultural layer varied from 30 to $60 \mathrm{~m}$ (Thomsen 1991).

The cultural layer in the Osilian harbour places found so far was also similar to settlement sites. On top of the hill at Tornimäe, where probably some buildings had been situated in the Viking Age, the intensely black soil was approximately $40 \mathrm{~cm}$ deep; on the slope, it could extend even to a depth of $70 \mathrm{~cm}$ (Mägi 1998a). The depth of the culture layer at the Viltina harbour site was up to $40 \mathrm{~cm}$ (Mägi 2000). In both cases, the soil can be characterised as intensely black, containing pieces of charcoal, burnt stones, animal and fish bones.

Small harbour sites in Estonia established in historical times can often be distinguished by parallel lines of stones stretching from sea to the coast - lauters. Similar constructions, characterised by massive earthen or stone walls and a depression in between, have been recorded in Norway, where they were interpreted 
as remains of boathouses. The same sort of boathouses also existed in Dalarna, central Sweden, as well as on the islands of Alland and Gotland (Grimm 2002). For some reason, such constructions seem to be rare in Denmark (Crumlin-Pedersen 1991a). In Estonia, the lauters mark places where boats were drawn up onto land.

When a harbour also acted as a market and trading place, a pier or jetty of wood or stone was undoubtedly erected on the shore. Some kind of jetties, perhaps with a lighter construction, have probably also existed in harbours of less importance. On Saaremaa, remains of a beam palisade found at Tornimäe, when ploughing there in the beginning of the 19th century, can be interpreted as traces of a probable jetty (Luce 1811); still, these data are very obscure. In Viltina, old people have said that oak beams or planks had been found next to the harbour site (Mägi 2000).

The majority of prehistoric harbours in the North were used seasonally, for instance only during the summer months (e.g. Westholm 1985; Ulriksen 1998). The same can be suggested for prehistoric harbour sites on Saaremaa.

\section{Cultural landscape around prehistoric harbour sites}

\subsection{Stone graves}

Although Carlsson has claimed a clear correlation between prehistoric harbour sites and graves on the seashore of Gotland, the theory has not been supported by Danish archaeologists. Flat burial grounds or low mounds in Denmark also cannot be considered as dominating landscapes as do stone graves on Gotland or Saaremaa. At Roskilde fjord, at least, the correlation between landing-places and graves on the shore seems to be absent (Ulriksen 1998, 113-142), neither has it been pointed out in the Fyn Research Project (Christoffersen 1996). In the case of Saaremaa, the Gotland example nevertheless seems to be appropriate: all stone graves known so far, which have been situated on the earlier coastline, mark areas that could on both natural and cultural evidence have been used for harbour sites. The phenomenon reaches back as early as the Bronze Age (e. g. Sõrve Lülle graves, Kihelkonna Kurevere graves, see topic 4), and becomes particularly evident in the latter half of the Iron Age. Some Viking Age harbour sites have been already located, using the occurrence of stone graves as the main criterion (e.g. Tornimäe, Viltina).

Who were these people who were buried in the graves close to prehistoric harbour sites? This is a separate question. At Viltina, it is reasonable to assume that a large stone grave with abundant grave goods was the burial ground of two or three local elite families who also controlled a harbour site $50 \mathrm{~m}$ away (Fig. 3). At least one of these families had formerly buried its dead in another grave, which was closer to their arable lands (the Randvere grave). At some time in the late Viking Age, probably owing to an increase of maritime activities, they had instead started to use the grave marking their harbour site. During the 11th-12th centuries, the old grave remained a burial place mainly for children while family members 


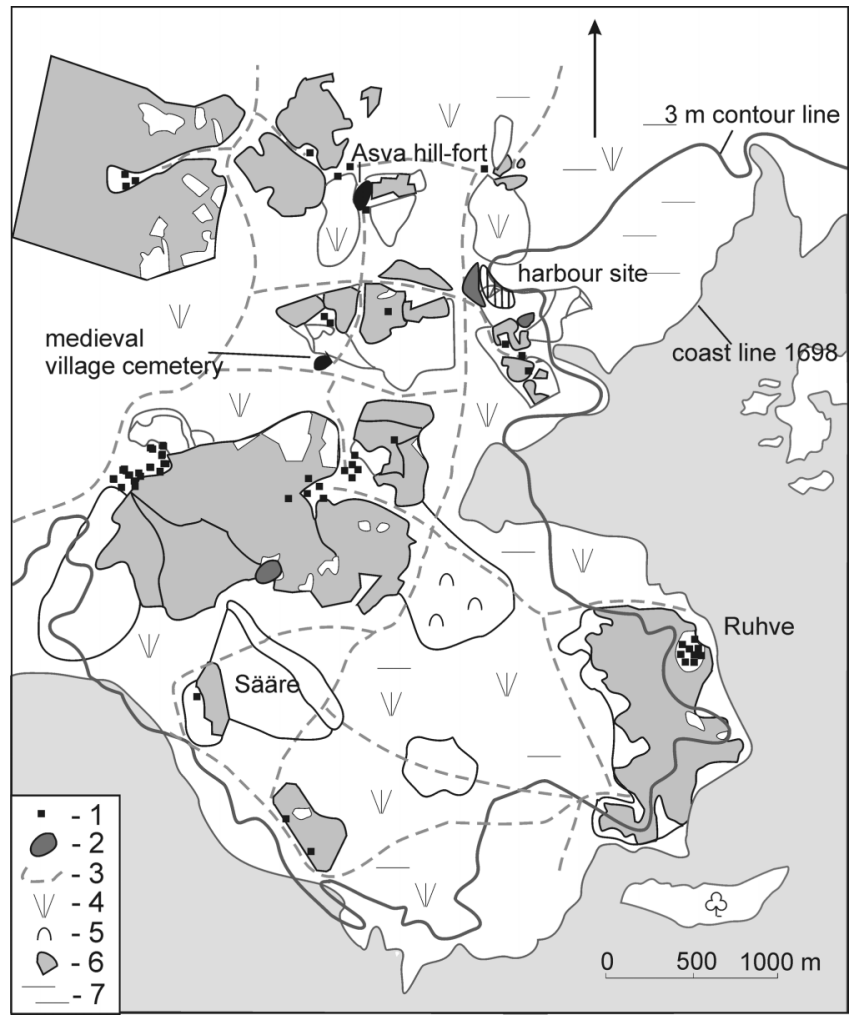

Fig. 3. Surroundings of the harbour site at Viltina. Redrawn from a 17 th-century map. 1 farm, 2 stone grave, 3 road, 4 meadow, 5 hillocks, 6 arable land, 7 wetland.

Joon 3. Viltina sadamakohta ümbritsev kultuurmaastik. Joonistatud 17. sajandi kaardi järgi. 1 talu, 2 kivikalme, 3 tee, 4 niit, 5 künkad, 6 põllumaa, 7 liigniiske ala.

who had died as adults were now buried in the harbour grave (Mägi 2002b, 47-49). Such practice probably reflects the need to demonstrate power and status. When the subsistence strategies of a settlement unit are thoroughly agricultural, power is often demonstrated through stone graves at the outline of arable lands or inside fields (for the connection between stone graves and settlement units on prehistoric Saaremaa see for more details Mägi 2002c). At Viltina, as probably in several other cases, maritime activities played a notable role in the local economy, which resulted in the erection of stone graves near to a place which was the most essential for the community - the harbour. ${ }^{4}$

4 This interpretation does not exclude other possibilities. For instance, the coast could have been chosen for a grave because of its liminal character: it was the border between land and sea, thus the border between two worlds. Still, Osilian stone graves that were in their time of erection situated on the seashore were clearly concentrated around areas which were also suitable for harbours. One possibility does not exclude the other; nevertheless, the rational aspect seems to prevail over the cognitive one (for the opposite opinion in Estonian archaeology see, for example, Lang 1999). 
It has been suggested that burial grounds around prehistoric harbour sites of more central importance have been the places where tradesmen and other visitors who had happened to die during their stay in the harbour or market place were buried. These men could of course have come originally from other districts or even lands. The idea is supported by the phenomenon that in the burial grounds around central trade places, the percentage of male burials is frequently higher, sometimes even several times higher than that of female burials. Such difference in gender has been reported for instance in Kaupang, southern Norway (Blindheim \& Heyerdahl-Larsen 1995) and Kopparsvik in Visby on Gotland (Lindquist 2003) it also seems to be the case at Laukskola, the biggest Livonian cemetery close to the trade centre of Daugmale in the lower reaches of the River Daugava ${ }^{6}$. In the case of international trade centres of more than regional importance, as for example Birka, even burial customs different from the local tradition have been pointed out (Gräslund 1980).

Harbour sites of more than regional importance are not known on Saaremaa, however. Still, some obscure data refer to unusual burials in the vicinity of some district harbour sites. For instance, uncremated human bones and some swords were found when digging graves in the later Orthodox cemetery near the Tornimäe site (SMM 1924, 102). In Laadjala, 1-1.5 km away from Upa, the possible main harbour of Kaarma district (see topic 2. 2), an inhumation burial of a man was found in 1866 (SMM 1924, 24), which can be dated to the Viking Age according to an one-edged sword and a scabbard. Viking Age Saaremaa was characterised by cremation as the dominant burial custom; the earliest Iron Age inhumation graves excavated on the island were dated to the end of the 12th century and weapons do not occur in them. Both above-mentioned burials are thus exceptional, found at the same time in the vicinity of certain or possible central harbour sites of the two wealthiest districts of the island.

\subsection{Churches and/or chapels}

Danish investigations have suggested that the erection of Romanesque churches on the seashore can be treated as a criterion for determining prehistoric/early medieval harbour sites (Ulriksen 1998, 130-132). In some cases, the same has been pointed out on Gotland (Carlsson 1999a; 1999b). On Saaremaa, which was Christianised late compared to Scandinavia, and where only ten stone churches were built in the Middle Ages, two churches can be considered as marking harbour sites: Kihelkonna and Püha. The churches of Jämaja and Anseküla on the peninsula of Sõrve, at this time a separate island, are also located quite close to the seashore.

5 The findings from this cemetery have so far been published only as a brief popular article.

6 The author is thankful to Latvian archaeologist Roberts Spirgis who kindly acquainted me with some material about Livonian cemeteries in the lower reaches of the River Daugava, collected by him, 2003-03-22. 
Chapels appearing here and there on the shore probably also marked harbour sites; still, most of them were presumably built of wood and are therefore not easy to detect. As an example, the Sääre chapel on the south-eastern end of Sõrve was, according to the local tradition of even as late as the 20th century, erected by local landowners for the sake of seafarers who stopped at Sääre harbour (Saaremaa 1934, 461).

As a means of demonstrating wealth and power, churches can often be compared with prehistoric stone graves: the elite of Saaremaa manifested its power through both of them (Mägi 2002b, 138-157). The erection of stone graves and churches/ chapels in the vicinity of more central harbour sites can thus be considered as largely equivalent phenomena. At the time when stone graves were erected close to harbour sites on Saaremaa and Gotland, the earliest Romanesque stone churches were being built in such places in an already Christianised Denmark.

\subsection{Manors and/or large farmsteads}

Maps used in the present research are dated mainly from the 17th-18th century, sometimes from the 19th century (for a more detailed overview of the historical maps of Saaremaa see Mägi 2002c). The majority of the maps are stored in the Estonian History Archive in Tartu; some can be found in the State Archive in Stockholm. These are predominantly agrarian maps where the main attention has been paid to soils, landscapes and farms. On the 17th-century maps, names of farmsteads were recorded; these maps are also precious because of the cultural landscape depicted there, which at this time was still unchanged by drainage or other improvements. Since the 18th century, micro-toponyms have been noted on maps, and the maps became more detailed. In some cases, a map of West-Estonia and the Estonian islands, drawn in 1650 and complemented in 1704, has been of great value (EA, 308-2-28; the part of Saaremaa and Muhu published in Mägi 2002c, Fig. 3). This map is not very detailed but reflects other relevant aspects, for instance, the impact of land mass elevation on the landscapes of Saaremaa.

The location of harbour sites abandoned centuries ago is often indicated on historical maps by roads running from different directions and meeting on the seashore at a seemingly meaningless point. Carlsson has demonstrated that Gotland harbour sites were often founded in places on the seashore, which were at more or less the same distance from the farms using them (Carlsson 1992). This seems to be quite often true on Saaremaa as well (e.g. Viltina, see Mägi 2000).

The roads united harbour sites with the centres of settlement units forming the hinterland of the harbour. Similarly to Scandinavia, these were probably manors or large farmsteads owned by the local elite. The owners of these estates controlled the harbour sites and the activities carried out there, although the harbours were most probably used by all local inhabitants. Since neither prehistoric nor medieval settlement sites have been excavated on Saaremaa so far, it has remained unknown 
whether single farmsteads or villages dominated the cultural landscape at this time. In 15th-century documents, however, both manors/enfiefments (some of them very small though, consisting of even less than one ploughland) and villages are mentioned. The variant of manor-in-a-village, when one of the households in a village is definitely larger than the others and is often situated somewhat apart, seems to occur frequently (Mägi 2002c). Villa mentioned by chronicler Henry the Livonian in the 13th century can also be interpreted as villages, although large single farmsteads can be marked with this name as well (CHL XI: 5, XV: 7, XXI: 5; Ligi 1968, 24-26).

As argued in my earlier writings, stone graves on Saaremaa seem to belong only to elite families. Even the most generous projections of the number of individuals buried in these graves result in figures that are far too small to represent the whole population; besides, the absolute majority of prehistoric graves have been recorded around manors known from medieval written sources. The graves thus mark the best arable lands, which have been owned by the elite ever since farming became the dominating subsistence industry (Mägi 2002b, 115-124; 2002c). Following the distribution of stone graves in settlement units bordering the sea, a connection between prehistoric manors (and, accordingly, stone graves around them) and harbour sites is obvious. In historical landscapes, i.e. on 17th-18thcentury maps, former harbour sites are frequently marked by a manor household situated 1-2 km away (e.g. Uuemõisa close to the Tornimäe harbour site; Fig. 4). Medieval manors have occasionally also been situated almost next to their harbours

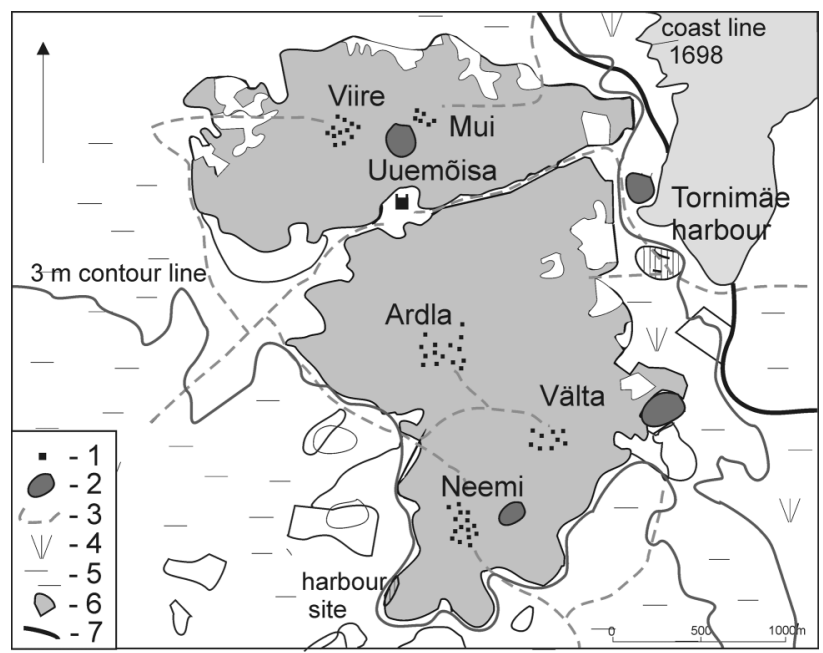

Fig. 4. Surroundings of the harbour site at Tornimäe. Redrawn from a 17th-century map. 1 farm, 2 stone grave, 3 road, 4 meadow, 5 wetland, 6 arable land, 7 river.

Joon 4. Tornimäe sadamakohta ümbritsev kultuurmaastik. Joonistatud 17. sajandi kaardi järgi. 1 talu, 2 kivikalme, 3 tee, 4 niit, 5 soo, 6 põllumaa, 7 jõgi. 
(e.g. Saaremõisa and Kihelkonna on Saaremaa or Suuremõisa on Muhu). However, the lack of prehistoric finds and stone graves in the vicinity of these manors indicates that they were founded only in the Middle Ages (Mägi 2001a).

There are several areas on Saaremaa where manors were not founded in the medieval period. In these cases, the location of harbour sites at an equal distance from surrounding villages is particularly obvious. An appropriate example might be the Viltina harbour site, which was presumably controlled by settlement units located at the sites of the later villages of Asva and Randvere (Fig. 3). Local elite families in these places certainly controlled the harbour; whether they lived in single farms in late prehistory, or whether the settlement pattern of villages and manors inside the villages already existed then, remains unclear until more specific investigation is carried out.

\subsection{Place names and local folklore}

Westerdahl in particular, but Carlsson too, have emphasised the significance of (micro)toponyms in the search for harbour sites (e.g. Carlsson 1991; Westerdahl 2002). Danish archaeologists seem to be more cautious, using this evidence only as a secondary indicator, and pointing to several problems in treating place names as source material (e.g. Holmberg 1996; Ulriksen 1998, 122-124). The use of place names has also been complicated on Saaremaa. On coastal areas, micro-toponyms referring, for example, to ships or boats can occasionally be found (e.g. Paadimägi - Boat Hill, Laevamägi - Ship Hill, Paadi Auk - Boat Hole); they can in any case also occur in places so far from the seashore that even prehistoric harbour sites should be excluded.

Somewhat surprisingly, a micro-toponym Linnamägi (Hill-Fort) has proved to indicate abandoned harbour sites in several cases. For instance, the hill of the Viking Age Tornimäe harbour was known as Linnamägi up to as late as the beginning of the 19th century (Luce 1811; EA, 2072-3-419), toponyms like Linnamäe Põld (Hill-Fort Field) and the Linna (Fort) farm occur in the vicinity of the Viltina harbour (EA, 3724-5-2946). A former island in what used to be the estuary of the River Maadevahe close to a Viking Age harbour site Kuru Saat, presently surrounded by wetland, is called Linnamägi; the same name is used for a wetland island in front of another probable harbour site (though small and of local importance) at Neemi (Mägi 1999a; 2001b; 2002a; 2004). Place names connected to power structures can be considered as symbols in the manifestation of authority over the landscape (see also Westerdahl 2002). Harbour sites apparently functioned as some kind of centres, and were therefore marked by names indicating their importance. It is essential to note that none of the abovementioned Linnamägi places were real hill-forts.

In identifying micro-toponyms on Saaremaa, predominantly historical maps, first of all 18th-19th-century land survey maps, have been used, since only a few elderly people remember the names in detail. The preliminary investigations have led to the 
somewhat surprising conclusion that place names often tend to change quickly. For instance, arable lands around the Tõnija village on southern Saaremaa are in 1873 marked on the map as Libbe maa peld and Surrid peld (EA, 3724-5-2492) while in the 1920s the same lands are already recorded as Kooljamäe põld (Field of the Hill of the Dead) and Hiiepõld (Field of the Holy Grove) (SMM 1924, 118-120). Present day local inhabitants, even the best informed ones, do not remember either of these names. The Tornimäe harbour site that was called Linnamägi (Hill-Fort Hill) on maps of the end of the 18th century (EA, 2072-3-419), was already known as Sillamägi (Bridge Hill) in the middle of the 19th-century (Holzmayer 1868), and in the beginning of the 20th century both these names were forgotten (see e.g. SMM 1924, 102-109). Despite these extreme examples, local place names, however, can often be used as at least complementary arguments, especially when the earliest variants are mentioned on 18th-19th-century maps.

In several cases, local folklore has helped in the localisation of prehistoric harbour sites. These data are usually very obscure and not pointing directly to harbours; for instance, local tradition can remember how far inland the sea reached "in the old times". As an example the village of Kogula can be cited, beside which a "town" was believed to have existed. The folklore of the beginning of the 20th century still remembered that a navigable sea had reached right under the walls of the "town" (SMM 1924, 88). According to contour lines on the topographic map, it must indeed have been like that about a thousand years ago, and the place at Kogula seems to be suitable for a harbour site. Old tradition also remembers how "old Estonians" were able to sail under the walls of the Valjala hill-fort; and in fact a tributary of the Lõve River reached right to this point even as late as in the 19th century, having disappeared mainly because of drainage work in later times. A lower area east of the Tornimäe harbour is remembered by some locals as an earlier navigable strait. According to contour lines there really was a strait, and the present Kõrkvere peninsula on the opposite side was an island even on the map of 1650 (EA, 308-2-28).

The research conducted so far has demonstrated that folklore data are worthy of consideration in all cases. The information in local stories is generally disguised, but nevertheless people have carried on the knowledge of the peculiarities of one place or another. Even legends of underground passages can, for instance, refer to a special connection between settlement units. It is interesting to note that, at least in two cases, prehistoric harbour sites are remembered in local tradition as abandoned manors, where some people have tried to find a hidden treasure. These data can be easily associated with the above stated connection between prehistoric harbour sites and medieval manors, as well as the use of the name Linnamägi in the vicinity of abandoned harbour sites.

No local tradition collected so far has directly recalled prehistoric or medieval harbour sites, while later historical harbours, "old village harbours", are frequently pointed out. The only exception is Tornimäe, which is known as a prehistoric harbour by all locals; still, this data is clearly obtained from published literature. 


\section{Discussion: harbour sites on Saaremaa and around the Baltic}

Different researchers have suggested that only harbour sites around the Baltic Sea dating from the 6th century onwards have become traceable (e. g. Carlsson 1991; Ulriksen 1998, 134-138, 194-195, 216-223). It does not mean that seafaring was not practised before that. Earlier harbour sites are evidently difficult to detect, perhaps because of infrequent use, which left fewer traces in the ground, or because of fewer ships in earlier periods. One possibility is that the use of river harbours was more widespread before the 6th century; this type of harbour is particularly complicated to distinguish (see topic 2.2). Another suggestion is that earlier than 6th century harbour sites are more difficult to find because of fewer metal items in their culture layer; at the same time, a great proportion of harbour sites have been identified in the course of metal detecting (e. g. Thrane \& Porsmose 1996; Ulriksen 1998, 17-19). It may be true for Estonia; on the other hand, very few settlement sites dated to the time before the 6th century have been excavated here, which makes it inadvisable to assume that such sites include fewer metal artefacts than later ones.

Single harbour sites dated earlier than the 6th century are however known in the countries around the Baltic as well - notably Lundeborg, a 3rd-7th-century harbour site on the south-eastern coast of the island of Fyn in Denmark. The site was linked to Gudme $4 \mathrm{~km}$ inland, a ritual centre where people presumably gathered to carry out religious rites, as well as for negotiations and other social activities. Since the place was situated on an island, the visitors arrived by boat. Some Danish archaeologists assume that neither Gudme nor its harbour at Lundeborg were controlled by one single chieftain but were regulated in common by several smaller chieftains (Crumlin-Pedersen 1991a; Thomsen 1991); others consider these sites as a result of power consolidation. Archaeological excavations at Lundeborg have proved it to have been a trade centre, where, among other material, items imported from the Roman Empire have been found. It can be assumed that it was a place where not only the chieftains but also their retainers and ships' crews arrived to trade and to conclude agreements (Ulriksen 1998, 218-219).

Lundeborg was probably not the only site of its kind. Even on Saaremaa, harbour sites earlier than the 6th century can theoretically be assumed. The concentration of Bronze Age and Pre-Roman Iron Age stone-cist graves on what used to be the seashore in these periods often correlates with topographic features suitable for a harbour site. The coast near a small bay on the southern part of the Bronze Age island of Sõrve, nowadays an area 1-1.5 km south-west of the village of Lülle, where a number of stone graves are recorded, can be cited as an example. In addition to stone cist graves, two Bronze Age ship-settings have been excavated here (Lõugas 1970). Taking into account the suitable small bay and arable lands around the present village of Lülle in the vicinity, a probable harbour site or at least a landing-place could be presumed here even without the stone graves (Fig. 5). 


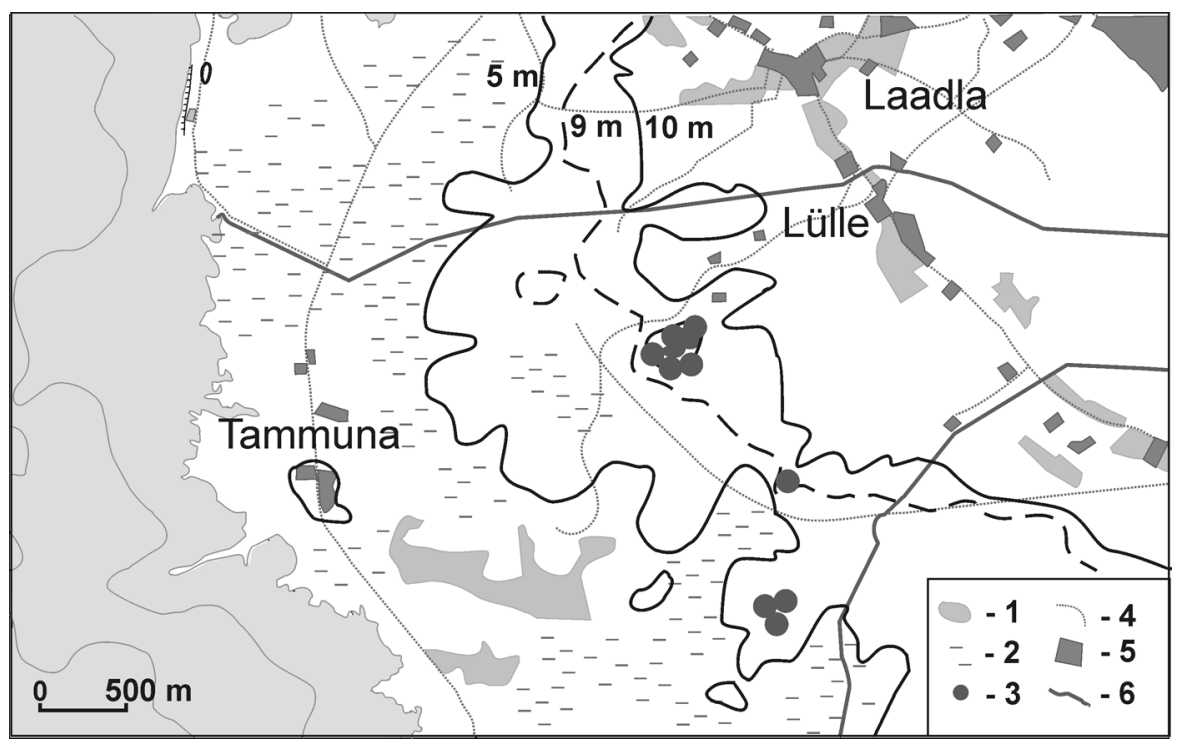

Fig. 5. Surroundings of the possible Bronze Age/Pre-Roman Iron Age harbour site at Lülle. Drawn using a present day map. 1 arable land (after land development), 2 wetland, 3 stone grave, 4 road, 5 dwelling site, 6 ditch.

Joon 5. Võimalikku pronksiaegset/eelrooma rauaaegset Lülle sadamakohta ümbritsev kultuurmaastik. Joonistatud nüüdisaegse kaardi järgi. 1 põllumaa (pärast maaparandust), 2 liigniiske ala, 3 kivikalme, 4 tee, 5 asula, 6 kraav.

A harbour site with a cult place nearby can be surmised at Kurevere on the north-western end of Saaremaa. A small bay stretching to the first houses of the present day village of Kurevere, with a suitably steep slope, on a coast where the water once became deep almost immediately, would have been a perfect place for a harbour for millennia. A road-embankment from the 20th century has unfortunately cut the former bay off from its outlet to the sea, causing the waterlogging of soils on the slope, thus complicating archaeological investigation (Mägi 2004; Fig. 6). The number of stone graves, as well as cup-marked stones, along the former coast of the bay is remarkable. The graves can be dated from the Bronze Age to the very end of prehistory, and some of them have been excavated (Kustin 1966; Lõugas 1977). 12th-century burials in particular were conspicuous by their abundant and luxurious grave goods (e.g. Mägi 2002b, 45-47).

Kurevere village itself is situated on the borderland of arable fields on unproductive soils, which suggests that it was established quite late, perhaps in the Middle Ages; the vicinity is sparsely populated even nowadays. The only village close by that is surrounded by arable lands is Tammese, $1.8 \mathrm{~km}$ towards the north-east, where recently a settlement site with a strikingly intensive prehistoric cultural layer was recorded (Mägi 2004). No burial grounds are known around the village of Tammese. The great number of stone graves concentrated around the 


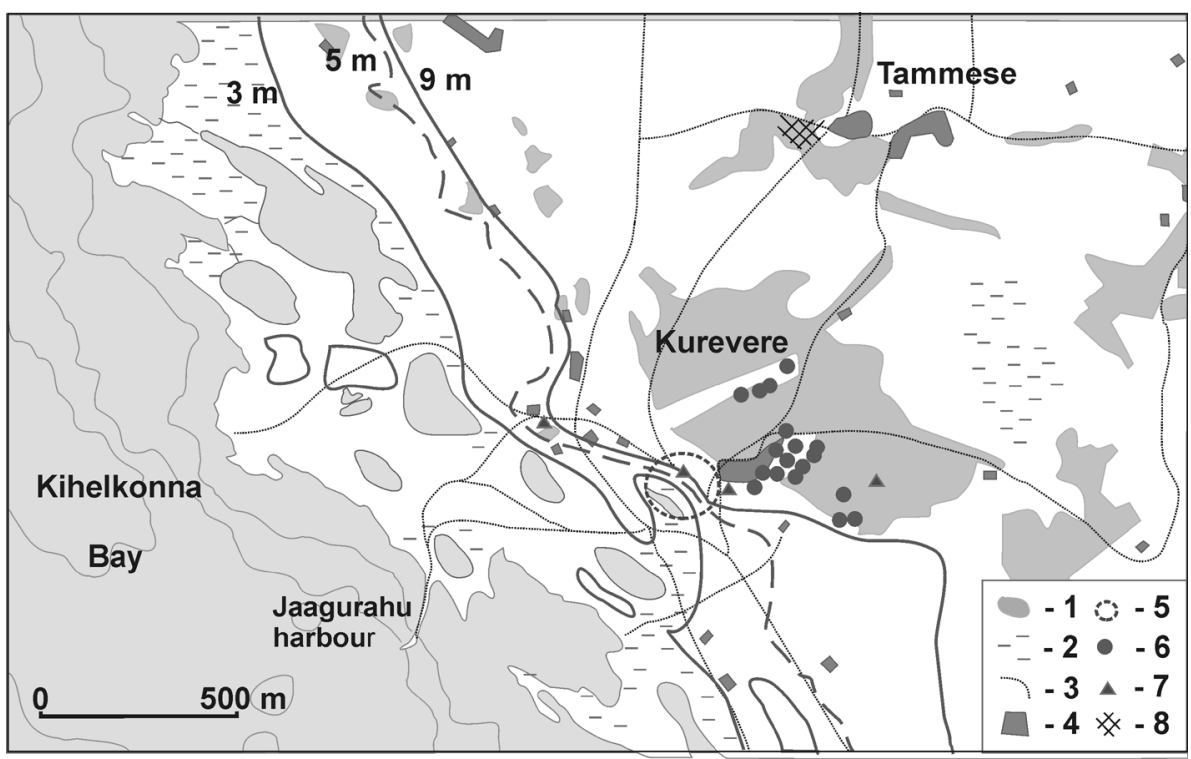

Fig. 6. Surroundings of the possible harbour site at Kurevere. Drawn using a present day map. 1 arable land (after land development), 2 wetland, 3 road, 4 present dwelling site, 5 probable harbour site, 6 stone grave, 7 cup-marked stone, 8 prehistoric dwelling site.

Joon 6. Kurevere võimalikku sadamakohta ümbritsev kultuurmaastik. Joonistatud nüüdisaegse kaardi järgi. 1 põllumaa (pärast maaparandust), 2 liigniiske ala, 3 tee, 4 praegune asulakoht, 5 arvatav sadamakoht, 6 kivikalme, 7 väikeselohuline kultusekivi, 8 muinasaegne asulakoht.

small bay and (possible) harbour at any rate suggests that Tammese and Kurevere should be considered as forming one complex of sites; presumably people from different settlement units were buried here. The settlement at Tammese very probably functioned as a ritual centre (which does not exclude other possible functions), or at least as an agrarian and perhaps political centre controlling ritual and social activities in the vicinity. The area is the easiest to reach by sea, and suitable topographic conditions for a harbour site therefore played a vital role in the formation of the whole complex.

The interest of an elite - noblemen or wealthier farmers - in controlling harbour sites was presumably associated primarily with trade and piracy, and only secondarily with more common maritime activities like fishing. Changes in harbour sites can anyhow be linked to social development. It can therefore be suggested that the less visible maritime activity before the 6th century was also the result of social conditions: single chieftains did simply not possess enough political power to control harbours with a larger hinterland. These were made possible only by gradual power consolidation before and during the Viking Age.

The 6th century is frequently pointed out as revolutionary in areas around the Baltic Sea. The adoption of new burial rites, together with other archaeological and historical evidence, indicate a strengthening of warrior ideology in society 
(e.g. Göransson 1999). In Estonia, changes occurred in the whole cultural sphere: earlier close connections with the eastern and south-eastern shore of the Baltic were gradually replaced by more intensive communication with the West. Changes in maritime activities were also indicated by the disappearance of coastal settlements, perhaps because it became too dangerous to live too close to the seashore (e. g. Crumlin-Pedersen 1991a; Näsman 1991; Christoffersen \& Porsmose 1996). Fishing villages moved back to the shore only in the medieval period, in the 13th-14th centuries (e. g. Crumlin-Pedersen 1996).

On Saaremaa, two harbour sites starting from the 6th or even the 5th century can be mentioned. As indicated by some single finds, the Tornimäe harbour site must have got its start in the 6th-7th centuries. A probable Migration Period harbour site Paemõis ("Limestone Manor"), excavated in 2003, was situated on the banks of the Maadevahe River, at the time of its use about $1 \mathrm{~km}$ upstream. It was separated from the surrounding area by a low wall (Mägi \& Mägi 2002; Mägi 2004).

Harbour sites around the Baltic became more "visible" starting in the 8th-9th centuries (e.g. Ulriksen 1998, 194-195, 217-223; Filipowiak 1999; Rẹbkowski 1999). Roughly at this time, Baltic Sea ships were equipped with sails, as far as it can be judged by depictions on picture stones (Westerdahl 1995; Ulriksen 1998, 219-222). It was the time when the use of the Tornimäe site was, according to present data, clearly intensified. Danish archaeologists have pointed out that the artefact material from harbour sites of this period alters: imported prestige ware was now complemented by imported but quite common items like bronze jewellery, glass beads and combs. This phenomenon is believed to be linked to the development of trade (Ulriksen 1998, 222-223). Norwegian archaeologist Axel Christophersen has pointed out the intensification of exploitation and distribution of resources which started at the end of the 8th century (Christophersen 1991). Social processes connected to this development brought along more effective control over trade, and centralisation of trade places. At harbour places of more central importance, visitors could now stay longer, for instance, for the whole summer season; craftsmen who were interested in selling their labour and production also joined them for a longer time. Merchants and other seamen visiting such places paid taxes to the chieftain(s) controlling the place, and the latter in turn guaranteed their safety for the time they stayed in the harbour. The greater part of archaeologically distinguishable late prehistoric harbour sites on Saaremaa presumably belonged to this category. At the same time, several small harbours probably existed parallel to the bigger ones, although traces of these are more difficult to detect.

The next change in the development of maritime activities around the Baltic was the move of harbour sites closer to the open sea in the 11th-12th centuries (for the phenomenon in Scandinavia see e. g. Callmer 1991). In Denmark, Ulriksen has associated the move with the drift of centres, and primarily the establishment of towns (Ulriksen 1998, 222-228). The phenomenon itself is however more comprehensive and apparent also in those Baltic regions where no towns developed in 
the 11th-12th centuries. It is more likely, therefore, that the move of harbour sites was predominantly caused by the increased speed of land mass elevation, and the appearance of large cargo-carrying ships, mainly since the 11th century. The end of the Viking Age and the 12th century were periods when the Viking Age high water level in the Baltic Sea sank, which, together with the ordinary processes of land mass upheaval, changed the coastline beyond recognition in a comparatively short time. Starting from the 11th century, the number of ships on the Baltic Sea definitely increased, and several different variants of sea craft appeared. Large cargo carriers were brought into use. By the 12th century, they could carry 60 tons - the same load as cogs, which entered the scene from the late 12th century onwards (Crumlin-Pedersen 1991b; 1991c). Drafts of these deepsea cargo carriers were also comparable with the cogs, extending to $1.5 \mathrm{~m}$ with a full load. All these changes meant that the 12th century is, according to current research, considered as the period of the major shift in northern ship-building (Crumlin-Pedersen 1999). Big new ships needed harbours with deeper water nearby, which resulted in the abandonment of several earlier harbour sites. This process was only accelerated by land mass elevation, which had in any case hampered access to several harbour sites.

The move of harbour sites at the end of prehistory is observable also on Saaremaa. Archaeological investigation conducted so far suggests that the Tornimäe Viking Age harbour site was abandoned by the 12th century, or was now used only for small boats. Another harbour site in front and beside the Muhu hill-fort on the opposite coast of the Little Strait can possibly be treated as a successor to Tornimäe. A stone pier about 500 m north-east of the Tornimäe Viking Age harbour place probably indicates a medieval harbour, which was probably connected to a taxation centre at Uuemõisa about 1300 m away. Similarly, the main harbour site of the Kaarma district had perhaps already moved to the site of the later Kuressaare by the end of prehistory, and the same may be true for the Maasi harbour.

The prosperity of prehistoric harbour sites came to an end at the beginning of the Middle Ages. In Scandinavia, the concentration of trade into single large harbours/ trade places started centuries earlier than on the eastern coast of the Baltic, and was caused by the centralisation of political power. These were early urban centres, whose usage and tax revenues were controlled by establishing kingships (Ulriksen 1998, 222-228). On Gotland, there were six main harbours in the Viking Age (Carlsson 1998). By the Middle Ages, all trade was concentrated in one place - the town of Visby (Westholm 1985), while all other harbour sites had been abandoned or functioned now only as small insignificant landing-places used only by some single farms.

On Saaremaa, harbour sites of more than regional importance never developed. Similarly to the island of Gotland, 5-6 more important harbour sites probably functioned more or less in parallel here up to the 13th century. Medieval towns that were founded on the Estonian mainland right after the conquest took over the international trade, and the Osilian harbours became marginal. On the sites of several earlier harbours, fishing villages were established. Only harbours connected 
to taxation centres retained some importance, though at a local level; the highest position was held by Maasi and Kuressaare, the harbours of the centres of medieval Osilian overlords. To a certain extent, Saaremaa harbours were still used throughout the following centuries, which is well indicated by the struggle that apparently was still hopeless at the end of the 16th century, to concentrate all trade into the harbour of Kuressaare (Seresse 1996, 75-77).

\section{References}

\section{Sources used}

EA, 308-2-28 - Map of Saaremaa and West-Estonia 1650/1704.

EA, 2072-3-419 - Map of the lands of Uuemõisa manor 1767.

EA, 3724-5-2946 - Map of Viltina and Asva villages 1874-75.

EA, 3724-5-2492 - Map of Rõõsa manor and farmsteads 1873.

\section{Printed sources}

Henriku Liivimaa kroonika. Heinrici Chronicon Livoniae (HCL). Translated and edited by E. Tarvel. Tallinn, 1982.

Liivimaa vanem riimkroonika. Translation and commentary by U. Eelmäe. Tallinn, 2003. (Older Rhyme Chronicle.)

\section{Unpublished reports}

Mägi, M. 1998a. Tornimäe sadam-asulakoht. Inspektsioonide aruanne. Manuscript in the Institute of History. Tallinn.

Mägi, M. 1999a. Aruanne inspektsioonidest Välta, Neemi ja Ardla küladesse Pöide kihelkonnas Saaremaal. Manuscript in the Institute of History. Tallinn.

Mägi, M. 2001a. Aruanne inspektsioonidest Saaremõisa ümbrusesse Pöide khk-s Saaremaal. Manuscript in the Institute of History. Tallinn.

Mägi, M. 2001b. Inspektsioonid Tõnija küla ümbrusesse. Manuscript in the Institute of History. Tallinn.

Mägi, M. 2002a. Kuru saat - sadamakoht Saaremaal Rõõsa külas (Valjala khk). Inspektsiooni aruanne. Manuscript in the Institute of History. Tallinn.

Mägi, M. 2003. Inspektsioon Upa külla Kaarma kihelkonnas Saaremaal 20. mail 2003. Manuscript in the Institute of History. Tallinn.

Mägi, M. 2004. Inspektsioonid Kurevere ja Tammese külla. Manuscript in the Institute of History. Tallinn.

\section{Literature}

Ambrosiani, B. 1991. Birka: its waterways and hinterland. - Aspects of Maritime Scandinavia AD 200-1200. Proceedings of the Nordic Seminar on Maritime Aspects of Archaeology, Roskilde, 13th-15th March, 1989. Roskilde, 99-104.

Atlas over Fyns kyst i jernalder, vikingetid og middelalder. Odense, 1996. 
Blindheim, C. \& Heyerdahl-Larsen, B. 1995. De dode. - Kaupang-funnene. (Bind II. Norske Oldfunn, XVI.) Oslo, 115-126.

Callmer, J. 1991. Platser med anknytning till handel och hantverk i yngre järnålder. Exempel från södra Sverige. - Høvdingesamfund og Kongemagt. Fra Stamme til Stat i Danmark, 2. (Jysk Arkæologisk Selskabs Skrifter, XXII, 2), 29-47.

Carlsson, D. 1991. Harbours and trading places on Gotland AD 600-1000. - Aspects of Maritime Scandinavia AD 200-1200. Roskilde, 145-158.

Carlsson, D. 1998. Vikingahamnar. Ett hotat kulturarv. (ArkeDok. Skrifter, 1.) Visby.

Carlsson, D. 1999a. Gård, hamn och kyrka. En vikingatida kyrkogård i Fröjel. (CCC papers, 4.) Visby.

Carlsson, D. 1999b. "Ridanäs". Vikingahamnen i Fröjel. Visby.

Christoffersen, J. 1996. Arkæologiske kilder. - Atlas over Fyns kyst i jernalder, vikingetid og middelalder. Odense, 33-42.

Christoffersen, J., Porsmose, E. 1996. Den fynske kystzones bebyggelsesmønstre i jernalder, vikingetid og middelalder. - Atlas over Fyns kyst i jernalder, vikingetid og middelalder. Odense, 154-160.

Christophersen, A. 1991. Ports and trade in Norway during the transition to historical time. Aspects of Maritime Scandinavia AD 200-1200. Proceedings of the Nordic Seminar on Maritime Aspects of Archaeology, Roskilde, 13th-15th March, 1989. Roskilde, 159-170.

Crumlin-Pedersen, O. 1991a. Maritime aspects of the archaeology of Roman and MigrationPeriod Denmark. - Aspects of Maritime Scandinavia AD 200-1200. Proceedings of the Nordic Seminar on Maritime Aspects of Archaeology, Roskilde, 13th-15th March, 1989. Roskilde, 41-54.

Crumlin-Pedersen, O. 1991b. Ship Types and sizes AD 800-1400. - Aspects of Maritime Scandinavia AD 200-1200. Proceedings of the Nordic Seminar on Maritime Aspects of Archaeology, Roskilde, 13th-15th March, 1989. Roskilde, 69-82.

Crumlin-Pedersen, O. 1991c. Søfart og samfund i Danmarks vikingetid. - Høvdingesamfund og Kongemagt. Fra Stamme til Stat i Danmark, 2. (Jysk Arkæologisk Selskabs Skrifter, XXII, 2), 181208.

Crumlin-Pedersen, O. 1996. Kystforsvaret. - Atlas over Fyns kyst i jernalder, vikingetid og middelalder. Odense, 182-193.

Crumlin-Pedersen, O. 1999. Ships as indicators of trade in Northern Europe 600-1200. - Maritime Topography and the Medieval Town. Papers from the 5th International Conference on Waterfront Archaeology in Copenhagen, 14-16 May 1998. Copenhagen, 11-20.

Filipowiak, W. 1999. Wolin und Szczecin - Hafen und Topographie der mittelalterlichen Stadt. Maritime Topography and the Medieval Town. Papers from the 5th International Conference on Waterfront Archaeology in Copenhagen, 14-16 May 1998. Copenhagen, 61-70.

Göransson, E.-M. 1999. Bilder av kvinnor och kvinnlighet. Genus och kroppssprak under övergangen till kristendomen. Stockholm.

Grimm, O. 2002. The military context of Norwegian boathouses AD 1-1500. - Maritime Warfare in Northern Europe. Technology, organisation, logistics and administration 500 BC-1500 AD. Papers from an International Research Seminar at the Danish National Museum, Copenhagen, 3-5 May 2000. Copenhagen, 105-123.

Gräslund, A.-S. 1980. Birka IV. The Burial Customs. A study of the graves on Björkö. Stockholm. Holmberg, B. 1996. Stednavne som historisk kilde. - Atlas over Fyns kyst i jernalder, vikingetid og middelalder. Odense, 53-60.

Holmquist Olausson, L. 2002. The fortification of Birka. Interaction between land and sea. Maritime Warfare in Northern Europe. Technology, organisation, logistics and administration 500 BC-1500 AD. Papers from an International Research Seminar at the Danish National Museum, Copenhagen, 3-5 May 2000. Copenhagen, 159-167.

Holzmayer, J. B. 1868. Osiliana, I. Das Kriegswesen der alten Oeseler. Arensburg.

Ilves, K. 2002. Merenduslik kultuurmaastik ja Maasi laev kui selle element. - EAA, 6, 2, 134-149. 
Kustin, A. 1966. Kiviringkalme Kureveres Saaremaal. - Pronksiajast varase feodalismini. Uurimusi Baltimaade ja naaberalade arheoloogiast. Tallinn, 87-95.

Lang, V. 1996. Muistne Rävala. Muistised, kronoloogia ja maaviljelusliku asustuse kujunemine Loode-Eestis, eriti Pirita jõe alamjooksu piirkonnas, 1-2. (MT, 4.) Tallinn.

Lang, V. 1999. Kultuurmaastikku luues. Essee maastiku religioossest ja sümboliseeritud korraldusest. - EAA, 3, 1, 63-85.

Lang, V. 2000. Keskusest ääremaaks. Viljelusmajandusliku asustuse kujunemine ja areng VihasooPalmse piirkonnas Virumaal. (MT, 7.) Tallinn.

Ligi, H. 1968. Talupoegade koormised Eestis 13. sajandist 19. sajandi alguseni. Tallinn.

Lindquist, M. 2003. Masculine - feminine - human - about the Viking-age grave-field at Kopparsvik south of Visby, Gotland. - Viking Heritage magazine, 2003, 1, 11-13.

Lõugas, V. 1970. Sõrve laevkalmed. - Studia archaeologica in memoriam Harri Moora. Tallinn, $111-118$.

Lõugas, V. 1977. Ausgrabungsergebnisse eines Steingräberfeldes von Kurevere. - TATÜ, 26, 1, $48-52$.

Luce, J. W. L. 1811. Das Schloss Mone auf Ösel, oder nähere Bestimmung der Lage derjenigen Festung, auf deren Einnahme durch die Deutschen 1225 die Unterwerfung der ganzen Insel folgte. Einladungsschrift der arensburgischen Kreisschule. Riga.

Lundström, P. 1985. Der Wall bei Västergarn. - Society and Trade in the Baltic during the Viking Age. (Acta Visbyensia, VII.) Visby, 269-272.

Mägi, M. 1998b. Districts and centres on Saaremaa 1100-1400. - Culture Clash or Compromise? The Europanisation of the Baltic Sea Area 1100-1400 AD. Papers of the XIth Visby Symposium held at Gotland Centre for Baltic Studies, Gotland University College, Visby, October 4th-9th, 1996. (Acta Visbyensia, XI.) Visby, 147-157.

Mägi, M. 1999b. Farmsteads and villages on Saaremaa from the late prehistoric to the medieval periods. Study of historical maps and archaeological evidence in Pöide district 1100-1400 AD. Europeans or Not? Local level Strategies on the Baltic Rim 1100-1400 AD. (CCC papers, 1.) Oskarshamn, 197-212.

Mägi, M. 2000. Weapons find and an ancient harbour site at Viltina Käo-Matsi. - AVE, 1999, 92-99.

Mägi, M. 2001c. Landed estates on Saaremaa 1100-1400 as recorded in a study of the parish of Pöide. - Lübeck Style? Novgorod Style? Baltic Rim Central Places as Arenas for Cultural Encounters and Urbanisation 1100-1400 AD. Transactions of the Central Level Symposium of the Culture Clash or Compromise (CCC) Project Held in Talsi September 18-21 1998. (CCC papers, 5.) Riga, 315-328.

Mägi, M. 2002b. At the Crossroads of Space and Time. Graves, Changing Society and Ideology on Saaremaa (Ösel), 9th-13th centuries AD. (CCC papers, 6.) Tallinn.

Mägi, M. 2002c. Piirkonnad ja keskused. Asustus muinasaja lõpu ja varakeskaegsel Saaremaal arheoloogiliste, inimgeograafiliste ning ajalooliste allikate andmeil. - Keskus - tagamaa - ääreala. Uurimusi asustushierarhia ja võimukeskuste kujunemisest Eestis. (MT, 11.) Tallinn; Tartu, 169-232.

Mägi, M. 2004. The mortuary house at Lepna on southern Saaremaa. - AVE, 2003, 45-60.

Mägi, M. \& Mägi, T. 2002. Archaeological fieldwork around Tõnija and Rõõsa on southern Saaremaa. - AVE, 2002, 56-64.

Näsman, U. 1991. Sea trade during the Scandinavian Iron Age: its character, commodities, and routes. - Aspects of Maritime Scandinavia AD 200-1200. Proceedings of the Nordic Seminar on Maritime Aspects of Archaeology, Roskilde, 13th-15th March, 1989. Roskilde, 23-40.

Österholm, I. 1991. Phosphate surveying of coastal settlements. - Aspects of Maritime Scandinavia AD 200-1200. Proceedings of the Nordic Seminar on Maritime Aspects of Archaeology, Roskilde, 13th-15th March, 1989. Roskilde, 269-274.

Rẹbkowski, M. 1999. The maritime topography of medieval Kołobrzeg. - Maritime Topography and the Medieval Town. Papers from the 5th International Conference on Waterfront Archaeology in Copenhagen, 14-16 May 1998. Copenhagen, 55-60. 
Saaremaa 1934 = Eesti. Maateaduslik, majanduslik ja ajalooline kirjeldus, IV. Saaremaa. Tartu. Saaremaa ja Muhu muinasjäänused. (Tartu Ülikooli Arheoloogiakabineti Toimetised, II.) Tartu, 1924 (= SMM 1924).

Seresse, V. 1996. Des Königs “arme weit abgelegenne Vntterthanen”. Ösel unter dänischer Herrschaft 1559/84-1613. Frankfurt am Main.

Thrane, H. \& Porsmose, E. 1996. Handelspladser og købstæder. - Atlas over Fyns kyst i jernalder, vikingetid og middelalder. Odense, 194-200.

Thomsen, P. O. 1991. Lundeborg: a traiding centre from the 3rd-7th century AD. - Aspects of Maritime Scandinavia AD 200-1200. Proceedings of the Nordic Seminar on Maritime Aspects of Archaeology, Roskilde, 13th-15th March, 1989. Roskilde, 133-144.

Ulriksen, J. 1998. Anløbspladser. Besejling og bebyggelse i Danmark mellem 200 og 1100 e. Kr. En studie af søfartens pladser på baggrund af undersøgelser i Roskilde Fjord. Roskilde.

Vedru, G. 2001. Põhja-Eesti muinasaegsest rannikukasutusest. - EAA, 5, 2, 110-127.

Westholm, G. 1985. The settlement at Vi, at the foot of the cliff. - Society and Trade in the Baltic during the Viking Age. (Acta Visbyensia, VII.) Visby, 293-304.

Westerdahl, C. 1980. On Oral Traditions and Place Names. An introduction to the first stage in the establishment of a register of ancient monuments for the maritime cultural heritage. - International Journal of Nautical Archaeology, 9, 4, 311-329.

Westerdahl, C. 1989. Norrlandsleden I. Källor till det maritima kulturlandskapet. Härnosand.

Westerdahl, C. 1995. Society and sail. On symbols as specific social values and ships as catalysts of social units. - The Ship as Symbol in Prehistoric and Medieval Scandinavia. Papers from an International Research Seminar at the Danish National Museum, Copenhagen, 5th-7th May 1994. Copenhagen, 41-50.

Westerdahl, C. 2002. The cognitive landscape of naval warfare and defence. Toponymic and archaeological aspects. - Maritime Warfare in Northern Europe. Technology, organisation, logistics and administration 500 BC-1500 AD. Papers from an International Research Seminar at the Danish National Museum, Copenhagen, 3-5 May 2000. Copenhagen, 169-190.

\section{Marika Mägi}

\section{“... NENDE SUURIM JÕUD ON LAEVAD." SADAMAD, PÕLLUD JA PEALIKUD SAAREMAAL}

Raske oleks leida teist Eesti muistset maakonda, mis oleks olnud merendusega nii tugevalt seotud kui Saaremaa. Saareline asend räägib iseenda eest. Seotusele mere ja rannajoonega viitab siinne asustusmuster, ülemeresidemetest kõnelevad mujalt toodud esemed arheoloogilises materjalis. Kaalukas sõna on öelda kirjalikel allikatel, mis pea eranditult rõhutavad saarlaste laevastiku tugevust ja kindlustunnet eriti suvisel ajal, mil saarele pääsemine ilma laevadeta oli raske. Ometi võib kindel olla, et saarlaste merenduslik aktiivsus polnud üksnes rüüstamisega seotud: hoopis olulisemad olid kala- ning hülgepüük, kaubandus ja kontroll rahvusvahelise kaubanduse üle.

Käesolev artikkel on ülevaade seni tehtud uurimistööst Saaremaa merendusliku maastiku vallas. Põhitähelepanu on selles keskendatud muinasaja lõpusajandeile ning varakeskajale, seega ajavahemikule umbes 900-1400. 


\section{Uurimisaines}

\subsection{Pôllumajanduslik ja merenduslik maastik}

Rannamaastiku all pole mõistetud üksnes otseselt mereäärseid alasid, vaid ka asustusüksusi, mis piirnevad või piirnesid kunagi merega. Muinas- ja keskaegsed asustusüksused Saaremaal olid oma põhiiseloomult agraarsed ning koosnesid elu- ja muudest hoonetest, neis elavate inimeste haritavatest põldudest, nende kasutatavatest heina- ja karjamaadest ning muudest kõlvikutest. Seda inimese poolt mõjutatud maastikku nimetatakse kultuurmaastikuks. Rannalähedastel aladel liitub eelkirjeldatule veel üks oluline aspekt, mida tuleks õieti vaadelda tihedas sümbioosis eelnevaga. See on merega seotud inimtegevus, mille nähtavateks arheoloogilisteks jälgedeks on kunagised sadamakohad, aga ka näiteks koolmening sillakohad ja laevavrakid. Inimtegevuse, loodusliku rannamaastiku ning rannalähedase mere topograafia koosmõjus sünnibki merenduslik kultuurmaastik.

\subsection{Sadamakohad}

Omaette küsimuseks on, kus jookseb piir muistsete sadamakohtade ning lihtsalt laevade randa tõmbamise kohtade vahel. Varasemad uurijad on kasutanud eri termineid. Käesolevas kirjutises on sadamakoht kui veesõidukitele ligipääsetav merenduslikule tegevusele orienteeritud koht, mille kasutamine on olnud reguleeritud kokkulepete ja/või traditsioonidega ning mida iseloomustab tagamaa olemasolu. Seega ei peeta sadamakohtadeks juhusliku iseloomuga maabumiskohti, mida, tõsi küll, on ka arheoloogilises materjalis praktiliselt võimatu eristada.

Sadamakoha tagamaa all mõistetakse ala, millega üks või teine sadamakoha funktsioon on otseselt seotud. Tagamaa ulatus võib olla väga erinev ning sõltub sadamakoha funktsioonidest ja tähtsusest. Kalastamise, kohaliku vahetuskaubanduse ja esmatasandi kommunikatsiooniga seotud sadamakoha tagamaa moodustavad seda kasutanud agraarse iseloomuga asustusüksus või -üksused. Kauplemisja/või käsitöökeskusena funktsioneeriva sadamakoha tagamaaks on enamasti laiem piirkond, näiteks muinaskihelkond. Varalinnalise või linnalise keskusega seotud kaubasadamad on tavaliselt seotud rahvusvahelise kaubandusega ning nende tagamaa puhul võib rääkida regioonist. Saaremaa sadamakohtade puhul ei saa ilmselt rääkida (vara)linnalistest keskustest.

\subsection{Varasem uurimislugu}

Rannalähedaste alade asustusarheoloogia on Põhjamaades pälvinud arheoloogide eritähelepanu juba viimased 20-25 aastat. Eeskätt võiks mainida Dan Carlssoni pikaajalisi uuringud Saaremaa naabersaarel Ojamaal, kus praeguseks 
on välja selgitatud umbes 50 muinasaegset sadamakohta (Carlsson 1992; 1998; 1999b). Rootsi mandriosa merendusliku maastiku mõtestamisel on suure töö ära teinud Christer Westerdahl (Westerdahl 1980; 1989). Rohkesti on merendusliku ja agraarse kultuurmaastikuga tegeldud Taanis. Põhiliselt 1990. aastatel viidi Ole Crumlin-Pederseni juhtimisel läbi ulatuslik uurimisprojekt Fyni saarel, mis keskendus merenduslikule maastikule perioodil 500 BC-1500 AD (Atlas over Fyns kyst, 1996). Umbes samal ajal kaevas arheoloog Jens Ulriksen maabumiskohti Sjellandi saarel Roskilde fjordi ääres. Tema uurimused on avaldatud raamatuna, mida on käesolevas kirjutises ka rohkelt kasutatud (Ulriksen 1998). Põhja-Eesti rannamaastikku on spetsiaalselt käsitlenud Gurly Vedru (Vedru 2001; vt artikkel käesolevas numbris), merenduslikku kultuurmaastikku üldisemalt Kristin Ilves (Ilves 2002; vt artikkel käesolevas numbris). Saaremaa rannaasustuse ja sadamakohtadega on mõnevõrra varem tegelnud siinkirjutaja (Mägi 1999b; 2000; joon 1).

\section{Sadamakohad arheoloogilises materjalis}

\subsection{Otsimiskriteeriumid ja-meetodid}

Saaremaa kunagiste sadamakohtade otsinguil oleme lähtunud naabermaade kolleegide poolt välja töötatud meetoditest. See eeldab ulatuslikke kameraaltöid enne inspektsiooniretkedele asumist, fosfaatanalüüsi ja metalliotsija kasutamist kohapeal. Eri maade kogemused muistsete sadamakohtade leidmisel on pisut erinevad, seetõttu on inspektsiooniretkede käigus tulnud konkreetselt Saaremaa jaoks välja selekteerida kõige paremini sobivad meetodid ja indikaatorid.

Dan Carlsson on toonud välja kolm peamist kriteeriumi Gotlandi eelajalooliste sadamakohtade lokaliseerimisel. Need on: 1) kalmed ranna lähedal; 2) tugevate tuulte eest kaitstud kallas ja 3) tavapärasest erinev kultuurmaastiku ülesehitus 18.-19. sajandi katastriplaanidel (nt teede ristumiskoht näiliselt tühjal rannal või rannaäärne põllulapp ilma lähedal asuva taluta) (Carlsson 1991). Kõik nimetatud kriteeriumid kehtivad ka Saaremaal.

Ajalooliste plaanide ja kaasaegsete füüsilis-geograafiliste kaartide põhjal välja selekteerunud võimalikke sadamakohti on kontrollitud arheoloogiliste inspektsioonide käigus. Lisaks tavapärastele proovišurfidele on selleks kasutatud metalliotsijat ning fosfaatanalüüsi.

\subsection{Representatiivsus}

Sadamakohtade määratlemisel muistse Saaremaa kultuurmaastiku loomuliku osana on väga oluline lokaliseeritud sadamakohtade representatiivsuse aspekt: kui palju kunagi kasutusel olnud sadamakohtadest on suudetud leida või leitakse eeldatavasti tulevikus, kui paljude leidmine on raskendatud ning kui paljud võivad olla hävinud? Praeguste meetodite juures võib paraku väita, et vähe kasuta- 
tud muinasaegsete sadamakohtade, rääkimata randumiskohtadest, lokaliseerimine on peaaegu võimatu. Seetõttu on seatud eesmärgiks teha kindlaks mõnevõrra suurema tähtsusega sadamakohad, mille seos arheoloogiliste muististega tähistatud tagamaadega on ilmne. Sadamakohtade leidmist raskendab asjaolu, et tihti on samasse kohta tekkinud keskajal küla, mis eksisteerib sageli tänapäevalgi. Paljudel juhtudel on maastik arvatavas muistses sadamakohas kas maaparandus-, kruusavõtu- või muude töödega lihtsalt hävitatud (Upa Kaarma kihelkonnas, joon 2).

Ilmselt on kõige keerulisem leida jõesadamaid, kuna laugjal maastikul muudavad jõed tihti oma sängi ning veetaseme kõikumised neis on raskesti jälgitavad. Lisaks tuleb arvestada asjaoluga, et jõesadamatest saadud arheoloogiline materjal ei erine jõeäärse asulakoha omast ilmselt kuigivõrd.

\subsection{Asukoht}

Maastikuliselt sobivad randumiskohad on enamasti juba üksnes loodusgeograafilise kaardi põhjal tuvastatavad. Need on tuulte eest kaitstud kohad võimalikult hästi liigendatud rannal, tihti väikese merelahe ääres, kus neid tuulte eest varjab neemik või lahe suudmes paiknev saareke. Tähtis on, et kallas oleks randumiskohas sobivalt järsk ning et meri läheks kiiresti sügavaks. Merepõhi peaks olema liivane või kruusane. Sageli on randumiskoha lähikonnas allikas ja/või jõgi.

Kuigi looduslikult sobivaid randumiskohti võib Saaremaal leida rohkesti, on sadamad rajatud neist siiski vaid mõnesse. Siin tuleb mängu tagamaa olulisus. Saaremaa muinasaegsete sadamakohtade puhul on täheldatav nende otsene seos agraarse tagamaaga, st need paiknevad põllumajanduslikult sobivate maade lähikonnas. Soisest, liivasest või kivisest ümbruskonnast on muinasaegset sadamakohta mõttetu otsida. Siinkohal tuleb siiski meeles pidada, et jutt pole üksnes otseselt merega piirnevast vööndist, vaid kogu tagamaast, st põllumaad võivad jääda sadamakohast ka mõne kilomeetri kaugusele. Lisaks tuleb arvestada maakerkest ja muudest teguritest tingitud rannajoone muutusi.

\subsection{Sadamakohtade arheoloogilised jooned}

Naabermaadest teada olevatele sadamakohtadele on iseloomulik kultuurkihi ulatumine piki (kunagist) randa ja mitte kuigi palju sisemaa poole. Arheoloogilistel kaevamistel on leitud jäänuseid ehitistest, mille hulk ja laad sõltub koha tähtsusest ja konkreetsest funktsioonist. Arheoloogiline leiumaterjal pole sadamakohtades, suuremad kaubanduskeskused välja arvatud, kuigi rikkalik ning sarnaneb asulakohtade leiuainesele (Carlsson 1991; Thomsen 1991; Ulriksen 1998, 113-142). 
Juhul kui oli tegemist kauplemiskohaga, pidi seal kindlasti olema ka puust või kividest laevasild. Kergema konstruktsiooniga laevasillad olid ilmselt olemas ka vähem tähtsates sadamates.

Enamikku Põhjamaade muinasaegsetest sadamakohtadest kasutati sesoonselt, näiteks ainult suvekuudel (Westholm 1985; Ulriksen 1998). Sama võib oletada ka Saaremaa muinasaegsete sadamakohtade puhul.

\section{Kultuurmaastik sadamakohtade ümber}

\subsection{Kivikalmed}

Sarnaselt Ojamaale on enamikul kontrollitud juhtumitest, mil Saaremaa kivikalmed asetsevad omaaegsel rannal, tähistanud need kohta, mis looduslike ja kultuuriliste eelduste poolest sobiksid sadamaks. Kuigi see on täheldatav ka varasemate kalmete puhul (nt Lülle ja Kihelkonna kalmed), avaldub nähtus kõige selgemalt rauaaja viimasel perioodil, kus mõningatel juhtudel on kalmete läheduses paiknenud muistsed sadamakohad suudetud praeguseks lokaliseerida (nt Tornimäe ja Viltina; joon 3, 4).

Kivikalmeid omaaegsel rannikul võib pidada võimu manifestatsiooniks. Läbinisti agraarse asustusüksuse puhul demonstreeriti oma staatust kivikalmete näol põldude äärealal või põldudel (vt lähemalt Mägi 2002c). Juhul kui merelisel tegevusel oli asustusüksuse jaoks oluline tähtsus, rajati ka kalme ühe olulisema asustusüksuse osa - sadama - vahetusse lähedusse.

\subsection{Kirikud ja kabelid}

Taanis on täheldatud, et üheks varaste sadamakohtade lokaliseerimise kriteeriumiks on romaani stiilis kirikute rajamine nende lähedusse (Ulriksen 1998, 130-132). Teatud juhtudel esineb sama nähtus ka Gotlandil (Carlsson 1999a; 1999b). Saaremaal on otseselt sadamakohti tähistanud ilmselt vaid kaks kirikut, Kihelkonna ja Püha, lisaks on teateid rannikul paiknenud kabelite kohta.

Kivikalmete ja kirikute/kabelite püstitamist olulise tähtsusega sadamakohtade lähedusse võib vaadelda kui paljuski võrdväärseid nähtusi: eliit manifesteeris oma võimu nii ühtede kui ka teiste läbi (Mägi 2002b, 138-157). Ajal, mil Gotlandil ja Saaremaal rajati sadamate lähedusse kalmeid, püstitati tollal juba kristlikus Taanis samadesse kohtadesse esimesi romaani stiilis kirikuid.

\subsection{Talud ja mõisad}

Sadamakohtade kunagist asukohta tähistavad tihtipeale vanadele kaartidele märgitud teed, mis mitmest suunast lähtunult lõpevad näiliselt mõttetult mererannal. Teed ühendavad kunagisi sadamakohti nende tagamaa moodustanud 
asustusüksuste keskustega. Sarnaselt Skandinaavia maadele pidid needki olema eliidile kuulunud muinasmõisad-suurtalud. Nende omanikud kontrollisid sadamakohta ning seal toimuvat tegevust, kuigi sadamat kasutasid ilmselt ka ümbruskonna ülejäänud elanikud.

Carlsson on osutanud, et sadamakohaks valiti enamasti sobiv koht rannikul, mis jäi kohta kasutanud taludest, resp asustusüksuste keskustest, enam-vähem ühesugusele kaugusele (Carlsson 1992). Küllalt sageli näib sama seaduspära kehtivat ka Saaremaal (nt Viltina, vt Mägi 2000).

Olen oma varasemates kirjutistes osutanud, et kivikalmed koonduvad keskaegsetest allikatest teada olevate mõisate ümbrusse (Mägi 2002c). Vaadeldes kalmete levikut rannalähedastes asustusüksustes, võib nentida, et (muinas)mõisate (seega ka kivikalmete) ja tähtsamate sadamakohtade vahel valitseb selge seos. Ajaloolises kultuurmaastikus, s.o 17.-18. sajandi kaartidel, tähistabki kunagisi sadamakohti sageli nendest 1-2 km kaugusele jääv mõisasüda.

\subsection{Toponï̈̈mika ja folkloor}

Rannalähedastel aladel Saaremaal esineb kohati mikrotoponüüme, mis viitavad näiteks laevadele või paatidele (Paadimägi, Laevamägi, Paadi Auk vms), kõigil juhtudel ei osuta need aga ilmselt sadamakohale. Samas võib mõnevõrra üllatuslikult märkida, et vahel tähistab sadamakohti kohanimi Linnamägi. Nii on näiteks Tornimäe viikingiaegse sadamakoha küngast tuntud veel 19. sajandi algul Linnamäena (Luce 1811; EA, 2072-3-419), nimetused Linnamäe põld ja Linna talu esinevad ka Viltina sadamakoha lähiümbruses (EA, 3724-5-2946).

Üsna mitmel juhul on Saaremaa muistsete sadamakohtade lokaliseerimisel olnud täiendavaks argumendiks folkloor. Enamasti pole küll tegemist otseselt sadama mäletamisega, üsna hilisesse aega dateeritud "vanad külasadamad" välja arvatud. Erandiks on siinkohal Tornimäe, mille kohta käiv info on aga ilmselgelt juba publitseeritud kirjutistest hangitud. Pärimus võib jutustada näiteks sellest, kui kaugele on meri "vanal ajal" on ulatunud. Vähemalt kahel juhul on arvatavat sadamakohta nimetatud kunagiseks mõisaasemeks jne.

\section{Arutelu:}

\section{sadamakohad Läänemere maades ja Saaremaal}

Eri autorid on jõudnud seisukohale, et sadamakohad muutuvad Läänemere ruumis nähtavaks alates 6. sajandist pKr (Carlsson 1991; Ulriksen 1998, 134-138, 194-195, 216-223). Mõistagi ei tähenda see, nagu poleks enne meresõiduga tegeldud, varasemad maabumis-, resp sadamakohad, on arheoloogilises materjalis lihtsalt raskesti jälgitavad. Ilmselt oli laevu vähem, sadamakohti kasutati harvemini ning nendest ei jäänud märkimisväärseid jälgi. Pole ka võimatu, et kasutati rohkem jõesadamaid, mida on keerulisem leida (vt eestpoolt). 
Ka Läänemere ruumis on siiski teada üksikuid näiteid 6. sajandist varasemate sadamakohtade kohta. Eelkõige tuleks siinkohal mainida Taanis Fyni saare kagurannikul 3.-7. sajandil paiknenud Lundeborgi, mis oli ilmselt seotud $4 \mathrm{~km}$ eemal sisemaal asunud Gudme keskusega. Viimane oli eelkõige rituaalne keskus, kuhu nähtavasti koguneti regulaarselt teatud riituste läbiviimiseks, aga ka läbirääkimisteks või muuks ühiskondlikuks tegevuseks (Crumlin-Pedersen 1991a; Thomsen 1991).

Sadamakohtade olemasolu võib oletada ka 6. sajandist varasemal Saaremaal. Ühe näitena võib tuua pronksi- ja eelrooma rauaaegse Sõrve saare lõunaranniku, praegusest Lülle külast 1-1,5 km edela poole jääva omaaegse lahesopi, mille kallas on varase metalliaja kalmeid täis tipitud (joon 5). Arvestades, et sadamakoha eeldustena olid seal olemas nii sobiv lahesopp kui ka selle lähikonnas olevad põllumaad (mujal tolleaegse Sõrve saare rannikul nii soodsaid olusid aga ilmselt olla ei saanud), võiks seal kunagist sadama- või vähemalt maabumiskohta oletada ka ilma kivikalmeteta.

Juba pronksiajal alguse saanud sadama- ning selle läheduses paiknenud kultusekohta võiks oletada Saaremaa loodeosas Kureveres. Kuni hilisema Kurevere küla majadeni ulatunud, samas üsna sügava veega lahesopp oma sobivalt järskude nõlvadega võis sobida sadamakohaks mitme tuhande aasta jooksul (joon 6). Kahjuks on praeguse teetammi ehitamise järel oletatava sadamakoha nõlv liigniiskeks muutunud, mis raskendab selle arheoloogilist uurimist (Mägi 2004). Piki lahesopi kunagist randa leidub rohkesti kivikalmeid, alustades pronksiaegsetest kivikirstkalmetest ja lõpetades 12. sajandi kalmetega. Kurevere küla paikneb põllumaade äärealal väheviljakate muldade peal ja on seetõttu kindlalt üsna hilise tekkega. Lähim vana, põllumaade keskel paiknev küla on 1,8 km kirde poole jääv Tammese, kus on tuvastatud ka erakordselt intensiivne muinasaegne asulakiht (Mägi 2004). Seega võib oletada, et praegused Tammese ja Kurevere moodustasid ühtse kompleksi, millel võis kivikalmete ja lohukivide suure hulga järgi otsustades olla kultusliku keskuse funktsioone ning mille tekke vältimatuks eeltingimuseks oli soodne sadamakoht Kureveres.

6. sajandit on pea kõikjal Läänemere maades murranguliseks peetud. Omalaadsel moel viitab merelises tegevuses toimunud muudatustele varasema (lähi)rannikuasustuse kadumine hiljemalt 6. sajandil (Näsman 1991; Crumlin-Pedersen 1991a; Christoffersen \& Porsmose 1996), võib-olla seoses rannikul elamise ohtlikuks muutumisega. Kalurikülad ja muu asustus tekkis Läänemere rannikule tagasi alles keskaja algul, 13.-14. sajandil (Crumlin-Pedersen 1996).

Läänemerd ümbritsevates maades said sadamakohad veelgi "nähtavamaks" alates 8.-9. sajandist (Ulriksen 1998, 194-195, 217-223; Filipowiak 1999; Rẹbkowski 1999). Pildikivide järgi otsustades sai Läänemere muinaslaev umbkaudu sel ajal endale purje (Westerdahl 1995; Ulriksen 1998, 219-222). Ühiskondlik areng tingis eliidi tõhusama kontrolli kaubanduse üle, mis tõi ilmselt kaasa kaubitsemis-sadamakohtade koondumise. Sellistes kohtades võidi juba pikemaks ajaks paigale jääda, näiteks kogu suvesessiooniks; seal peatusid ka käsitöölised, 
kes olid huvitatud oma toodangu või teenuse müümisest. Sadamakohtade kasutamise eest maksid seal peatuvad laevnikud makse kohta kontrollivale pealikule, kes vastutasuks garanteeris neile sadamas viibimise ajaks julgeoleku.

Saaremaa ja üldse Läänemere sadamakohtade arengus toimus 11.-12. sajandil uus muutus, mis ilmnes sadamakohtade nihkumises n-ö merele lähemale (sama nähtuse kohta Skandinaavia maades vt Callmer 1991). Ulrikseni arvates võis see Taanis olla seotud keskuste nihkumisega ehk täpsemalt öeldes keskaegsete linnade kujunemisega (Ulriksen 1998, 222-228). Nähtus on siiski laiem ning täheldatav ka neis Läänemere regioonides, kus 11.-12. sajandil veel linnu ei kujunenud. Seepärast võib arvata, et sadamakohtade nihkumise tingis ühelt poolt maapinna järsk tõus, teisalt aga Läänemere laevade süvise kiire suurenemine alates 11. sajandist. Sel ajal võeti kasutusele suured kaubalaevad, mis 12. sajandiks suutsid võtta pardale vähemalt 60 tonni lasti - sama palju kui 12. sajandi lõpul kasutusele tulnud koged (Crumlin-Pedersen 1991b; 1991c). Taoliste suurte kaubalaevade süvis ulatus täislastis kuni 1,5 meetrini (Crumlin-Pedersen 1999). Mõistagi vajasid taolised laevad sügavama veega sadamakohti, mis muutis paljud varasemad sadamad kasutuskõlbmatuks, eriti kuna ligipääs neile oli tihtipeale läinud keerulisemaks juba maakerke tõttu.

Sadamakohtade nihkumine muinasaja lõpul on jälgitav ka Saaremaal. Praeguseks kogutud leiumaterjali põhjal võib oletada, et Tornimäe sadamakoht õigeusu kiriku all jäeti maha kas 12. sajandiks või kasutati seda ainult väiksemate paatide puhul, igal juhul näib 12. sajandi leiumaterjal seal senistel andmetel puuduvat. Võimalik, et Tornimäe järeltulijaks sai Väikese väina vastaskaldal Muhu linnuse ees ja kõrval lokaliseeritud sadamakoht. Keskaegseks võib pidada Tornimäe viikingiaegsest sadamakohast umbes $500 \mathrm{~m}$ kirde poole jäävat kividest paadisilda. Tõenäoliselt oli see Uuemõisa maksukogumiskeskuse n-ö tagasadam. Sarnaselt nihkus ilmselt juba muinasaja lõpul Kaarma piirkonna tähtsaim sadamakoht hilisema Kuressaare kohale, sama protsess võis toimuda ka Maasi sadama juures.

Muinasaegsete sadamakohtade õitseng lõppes keskaja saabumisel. Mujal Põhjamaades sai kaubanduse koondumine üksikutesse sadamakohtadesse alguse juba sajandeid varem ning oli seotud seal varem kujunenud keskvõimuga. Need olid viikingiaegsed varalinnalised keskused, mille kasutamist ja nende pealt laekuvaid makse kontrollis kujunev kuningavõim (Ulriksen 1998, 222-228). Ojamaal koondus kaubandus viikingiajal 6 suuremasse sadamakohta, millest keskajaks jäi püsima vaid Visby (Westholm 1985).

Saaremaal regionaalse tähtsusega viikingiaegseid kaubanduskeskusi ei tekkinud. Ilmselt oli seal sarnaselt Ojamaaga 5-6 tähtsamat sadamakohta, mis funktsioneerisid paralleelselt vähemalt 13. sajandini. Pärast vallutust Lääne-Eestisse kiiresti tekkinud linnad koondasid endasse rahvusvahelise kaubanduse, muutes Saaremaa sadamad marginaalseks. Paljudesse sellistesse, nüüd vähetähtsatesse sadamakohtadesse tekkisid kalurikülad. Teatud määral kasutati sealseid sadamaid siiski ka järgnevatel sajanditel, millest annab tunnistust kas või veel 16. sajandi lõpul lootusetuna tundunud võitlus koondada kaubandus üksnes Kuressaare sadamasse (Seresse 1996, 75-77). 